\title{
Evidentials as epistemic modals: Evidence from St'át'imcets*
}

\author{
Lisa Matthewson, Henry Davis and Hotze Rullmann \\ University of British Columbia
}

\begin{abstract}
This paper argues that evidential clitics in St'át'imcets (a.k.a. Lillooet; Northern Interior Salish) introduce quantification over possible worlds and must be analyzed as epistemic modals. We thus add to the growing body of evidence suggesting that the functions of encoding information source and encoding epistemic modality are not necessarily distinct. However, St'át'imcets evidentials differ from English modal auxiliaries not only in that the former explicitly encode the source of the speaker's evidence, but also in that they do not encode differences in quantificational force. We therefore argue that distinguishing quantificational strength is not an intrinsic property of modal elements.

With respect to the syntax-semantics interface, we argue on the basis of data from St'át'imcets against attempts to establish a universally fixed position for evidentials in the functional hierarchy. We conclude that evidentiality is not a homogeneous category, either semantically or syntactically. On the semantic side, cross-linguistically and even
\end{abstract}

\footnotetext{
*We are very grateful to St’át'imcets consultants Gertrude Ned, Laura Thevarge, Rose Agnes Whitley and the late Beverley Frank. We are also very grateful to Rose-Marie Déchaine, Martina Faller, Angelika Kratzer and Martina Wiltschko for helpful feedback and suggestions, as well as audiences at the University of British Columbia, the Paris Conference on Time and Modality, and the 41st International Conference on Salish and Neighbouring Languages. Errors are our own. This research is supported by SSHRC grants \#410-2002-1715, \#410-2203-1138, and \#410-2005-0875.
} 
within a single language, elements which encode information source may or may not fall into the category of epistemic modals (as already argued by Faller 2002, to appear). On the syntactic side, evidentials in most languages do not form grammaticalized systems and are not confined to a single position in the functional hierarchy. We suggest that evidentiality per se is a 'parasitic' category, since evidential meanings may be associated with any of the principal functional heads in the IP domain: mood, tense, or aspect.

\section{$1 \quad$ Introduction}

In this paper we argue that evidential markers in St'át'imcets (a.k.a. Lillooet; Northern Interior Salish) introduce quantification over possible worlds, and are restricted to epistemic conversational backgrounds. Thus, the St'át'imcets evidentials fall squarely into the category of epistemic modals. On the other hand, we also show that the St'át'imcets evidentials differ from English modal auxiliaries in two respects: the St'át'imcets evidentials explicitly encode the source of the evidence for the modal claim, and they do not encode differences in quantificational force.

Our proposals have consequences for a debate within current literature about the status of evidential markers, as well as for the theory of modals in general. Like Kratzer (1991), Izvorski (1997), Garrett (2000), Ehrich (2001), Rooryck (2001a), McCready and Asher (2005), McCready and Ogata (2006) and Faller (to appear), we argue that at least some evidentials in some languages are epistemic modals. Thus, it cannot be right that evidentiality is fundamentally distinct from epistemic modality, as has been argued by e.g., de Haan (1999). De Haan claims that evidentiality encodes the source of the information contained in the utterance, while epistemic modality encodes the degree of commitment on the part of the speaker to the truth of the information. He therefore proposes that an element which distinguishes only information-source is not a modal. Here we show that the St'át'imcets evidentials distinguish the source of the information, and do not encode 
distinctions of certainty / judgment / evaluation. They thus fall squarely into de Haan's evidential category. However, we also show that these elements must be analyzed as epistemic modals in the sense of being elements which quantify over epistemically accessible worlds. We thus reject the idea that it is an intrinsic requirement of a modal that it distinguish certainty or quantificational force. We therefore also reject Aikhenvald's (2004:7) claim that evidentiality and modality are 'fully distinct categories', with the latter category necessarily relating to the degree of certainty. ${ }^{1}$

On a broader level, we do not argue that all evidentials cross-linguistically are epistemic modals. On the contrary, Faller (2002) has provided convincing evidence that some evidentials in Cuzco Quechua are illocutionary operators. The current paper is one of very few attempts in the literature to apply a rigorous set of empirical tests which distinguish a modal analysis from an illocutionary operator analysis of evidentials (see McCready and Ogata 2006, Faller to appear for two others). Our paper therefore serves to confirm Faller's claim that evidentials vary crosslinguistically in their modal status.

The fact that evidentials do not form a homogeneous semantic class - and in particular the fact that some evidentials are illocutionary operators, while others are not - has implications for the syntax-semantics mapping. In particular, it casts doubt on attempts to establish a universally fixed position in the functional hierarchy where evidentials are located (see e.g., Hengeveld 1990, van Valin and La Polla 1997, Cinque 1999, Speas 2004, 2006). On the other hand, it may be compatible with a 'distributed' mapping of evidentials onto the syntactic architecture, as suggested by Chung

${ }^{1}$ Some have argued that distinctions in information source are simultaneously distinctions in certainty. Thus, for example, a visual information source leads to greater certainty than an indirect inferential information source (see e.g., Bybee 1985). However, see Faller (2002:96-98) for arguments that such correlations are at best indirect and context-dependent. 
(2005) for Korean and Blain and Déchaine (in press) for the Cree dialect continuum.

The St'át'imcets evidentials analyzed in this paper are listed in (1); an example of the use of each is given in (2-4). ${ }^{2}$ Syntactically, the evidentials are all second-position clitics. ${ }^{3}$

(1)

\begin{tabular}{|l|l|}
\hline evidential & gloss \\
\hline$k u 7$ & reportative \\
\hline$k^{\prime} a$ & inferential \\
\hline$-a n^{\prime} 4$ & perceived evidence \\
\hline
\end{tabular}

2 All data come from original fieldwork unless otherwise stated. All data are presented in the official St'át'imcets orthography, developed by Jan van Eijk (see van Eijk 1997).

${ }^{3}$ In addition, the demonstrative adverb lákw7a, which will be discussed in 7.2 below, has a clearly evidential meaning, referring to knowledge based on non-visual perception (hearing, smell, taste). The language also possesses two 'evaluative' clitics which might fall into the class of evidentials, and which will be the subject of future research: cwilh 'contrary to expectations' and qa7 'presupposed knowledge'.

4 -an' differs morphosyntactically from the other two evidentials in several ways. First, it obligatorily induces conjunctive subject morphology; second, it precedes rather than follows the enclitic - $a$ which occurs with existence-asserting determiners, as well as the suffix - $a$ which forms part of the discontinuous 'out-of-control' morpheme. Finally, in its phonological shape -an' resembles an affix rather than a clitic, since (aside from -a) vowel-initial clitics are disallowed. The last two features account for the orthographic convention whereby -an' is written together with the preceding word, whereas $k^{\prime} a$ and $k u 7$ are not. We will return to these differences in 7.2 below. 
(2)

wa7 ku7 ku sts'éts'qwaz' 1-ta stswáw'cw-a

be REPORT DET trout in-DET creek-DET

'[I heard] There are trout in the creek.'

(3) plan $k^{\prime} a$ tu7 wa7 tsu7c na máq7-a

alreadyINFER then IMPF melt(INCH) DET snow-DET

'The snow must have melted already.' $\quad$ (Davis in prep.: chapter 23)

(4) pel'p-s-ácw-an' nelh neklíh-sw-a

lost-CAUS-2SG.CONJ-PERC.EVID DET.PL key-2SG.POSS-DET

'It looks like you've lost your keys.' (Davis in prep.: chapter 23)

The structure of the paper is as follows. In section 2 we show that $k u 7, k^{\prime} a$, and -an' encode distinctions of information source. In particular, they are reportative, inferential, and perceivedevidence evidentials, respectively. In section 3 we outline the two major analyses of evidentials in the formal semantic literature: an epistemic modal analysis (following Izvorski 1997), and an illocutionary operator analysis (Faller 2002). In section 4 we outline and then test a range of predictions made by each of these approaches. We show that the St'at'imcets evidentials obey the predictions of the modal analysis, and disobey the predictions of the illocutionary operator analysis. We conclude that $k u 7, k^{\prime} a$ and -an' are epistemic modals. ${ }^{5}$ In section 5 we show that the

\footnotetext{
5 In Matthewson, Rullmann and Davis $(2005,2006)$ and in Rullmann, Matthewson and Davis (2006) we argued that $k^{\prime} a$ was an epistemic modal. The present paper provides more in-depth argumentation for this claim, as well as extending the analysis to $k u 7$ and $-a n^{\prime}$.
} 
St'át'imcets evidentials differ from English modal auxiliaries in that the former do not encode distinctions of certainty or quantificational force. Section 6 provides a formal analysis which accounts for the generalizations presented in the paper. Section 7 discusses the implications of our findings for the syntax-semantics mapping, and Section 8 concludes.

\section{The St'át'imcets modals encode distinctions of information source}

Each of the clitics in (1) above indicates something about the source of the information presented in the proposition. All the clitics therefore fall within the standard set of evidential meanings which are found cross-linguistically, and also within the definition of evidentiality assumed by e.g. de Haan (1999), Anderson (1986), Bybee (1985:184), Aikhenvald (2004:3), among many others. Willett's (1988) categorization of evidentials (based on a study of 38 languages) is given in (5). Those categories which correspond to St'át'imcets clitics have been highlighted.

$\begin{array}{ccc}\text { Types of Evidence (Willett 1988:57) } \\ \text { Direct } & \text { Reported } & \text { Inferring } \\ \text { Attested } & \text { Indirect } \\ \text { Visual } & \text { Second-hand } & \text { Results } \\ \text { Auditory } & \text { Third-hand } & \text { Reasoning } \\ \text { Other sensory } & \text { Folklore } & \end{array}$

In this section we first show that according to Willett's categorization, $k u 7$ is an indirect reported evidential. $k u 7$ covers all reportative cases; it does not specify whether the report is second-hand, third-hand, or derives from folklore. We call $k u 7$ 'reportative' for short. We then show that $k^{\prime} a$ is an indirect inferring evidential. $k^{\prime} a$ is felicitous in all cases involving inference; it 
does not specify whether the inference is based on observable results or solely on reasoning. We call $k^{\prime} a$ 'inferential' for short. Finally, we argue that -an' is an indirect inferring evidential of results; any claim made using -an' must be based on perceived evidence. We call -an' 'perceived evidence' for short.

First let us look at $k u 7$. A sentence of the form $[k u 7 \varphi]$ is felicitous whenever the speaker came to believe the content of $\varphi$ by means of a report from some other person. $k u 7$ may be used regardless of whether the report is second-hand, third-hand, or folklore: this is illustrated in (6-9). Note that Willett's category 'third-hand' is not restricted literally to third-hand reports. Rather, any case where the speaker has heard about the situation from someone who did not themselves directly witness the situation is classified as third-hand. 'Folklore' cases are those where the speaker claims that the situation described is part of established oral history.

(6) Second-hand context: Speaker is talking about a time during her childhood when a chicken attacked her. The speaker does not remember the occasion, but was told about it by her mother, who witnessed it.

$\begin{array}{lll}\text { wá7-lhkan } & k u 7 & \text { nq'san'k } \\ \text { IMPF-1SG.SUBJ } & \text { REPORT } & \text { laugh }\end{array}$

'[I was told that] I was laughing.' ～～(Matthewson 2005:380)

(7) Third-hand context: Speaker is talking about the birthplace of her grandmother's mother. She was told about this by one of her relatives, but not by anyone who witnessed the birth. l-ta cácl'ep-a $\quad k u 7 \quad$ lh-kwís-as $\quad k u \quad$ skícza7-s in-DET Fountain-DET REPORT HYP-fall-3CONJ DET mother-3POSS 'Her mother was born at Fountain.' (Matthewson 2005:391) 
(8) Third-hand context: Speaker is talking about when she heard bells ringing everywhere, and she was told that the bells were ringing because World War II had ended.

nilh $k u 7 \quad$ i $\quad$ tsúkw-as k-wa q’eltw'ácw kenkw7ú Europe-a

FOC REPORT when.PAST finish-3CONJ DET-IMPF wage.war DEIC Europe-DET

'That was when they stopped fighting in Europe.' $\quad$ (Matthewson 2005:454)

(9) Folklore context: First line of a legend 'The Dog Children'.

wá7 ku7 láti7 ti pápel7-a smúlhats

be REPORT DEIC DET One(HUMAN)-DET woman

'There was this woman.' (van Eijk and Williams 1981:32; told by Martina LaRochelle)

The data in (6-9) confirm that $k u 7$ falls under Willett's definition of a general reported evidential.

Turning to $k^{\prime} a$ and - $a n^{\prime}$, we find that these are both indirect inferring evidentials. The

distinction between the two sub-types of indirect inferring evidentials is given in (10) (from Willett 1988:96):

(10) i. Inference from results: the speaker infers the situation described from the observable evidence (i.e. from perception of the results of the causing event or action.)

ii. Inference from reasoning: the speaker infers the situation described on the basis of intuition, logic, a dream, previous experience, or some other mental construct.

The data reveal that $k^{\prime} a$ is a general indirect inferring evidential: it does not specify whether the inference is based on observable results or solely on mental reasoning. -an', on the other hand, is 
restricted to cases where the inference is based on perceived results. ${ }^{6}$ Thus, $-a n^{\prime}$ is usable in a subset of cases in which $k^{\prime} a$ is. This is illustrated in (11-12) (adapted from data in Izvorski 1997). In (11), there is no observable evidence; the assertion is based only on reasoning, and only $k$ ' $a$ is good. In (12), there is observable evidence, and both $k^{\prime} a$ and -an' are good.

(11) Context: You had five pieces of ts'wan (wind-dried salmon) left when you checked yesterday. Today, you go to get some ts'wan to make soup and you notice they are all gone. You are not sure who took them, but you know that John is the person in your household who really loves ts'wan and usually eats lots whenever he gets a chance.
a. ts'aqw-an'-ás $\quad k^{\prime} a \quad$ i $\quad$ ts'wán-a kw s-John eat-DIR-3ERG INFER DET.PL wind-dried.salmon-DET DET NOM-John 'John must have eaten the ts'wan.'
b. ?? ts'aqw-an'-ás-an'
i ts’wán-a
kw s-John eat-DIR-3ERG-PERC.EVID DET.PL wind-dr.salmon-DET DET NOM-John 'John apparently ate the $t s$ 'wan.'

Consultant's comment re (b): “[Good] if he has bits of $t s$ 'wan on his shirt."

(12) Context: Same as above, except that this time, it's not just that you think it must be John because he's the one who likes ts'wan. This time, you see the ts'wan skins in his room.

\footnotetext{
${ }^{6}$ Davis (in prep.: chapter 23) observes that -an' 'refers to a situation where the speaker has come to a conclusion about the truth of an event on the basis of appearances.'
} 

a. ts'aqw-an'-ás $k^{\prime} a \quad$ i $\quad$ ts’wán-a kw s-John eat-DIR-3ERG INFER DET.PL wind-dried.salmon-DET DET NOM-John 'John must have eaten the $t s$ 'wan.'
b. ts'aqw-an'-ás-an' i ts'wán-a kw s-John eat-DIR-3ERG-PERC.EVID DET.PL wind-dr.salmon-DET DET NOM-John 'John apparently ate the $t s$ 'wan.'

Another minimal pair is given in (13-14). We see that when the deduction is based on reasoning rather than any observable evidence, only $k$ ' $a$ is felicitous (13); the presence of perceived evidence makes both $k^{\prime} a$ and -an' felicitous (14).

(13) Context: You are a teacher and you come into your classroom and find a caricature of you drawn on the blackboard. You know that Sylvia likes to draw caricatures.
a. nilh $k^{\prime} a \quad$ s-Sylvia $\quad \mathrm{ku} \quad$ xílh-tal'i
FOC INFER NOM-Sylvia DET do(CAUS)-TOP
'It must have been Sylvia who did it.'
b. \# nílh-as-an'
s-Sylvia $\quad \mathrm{ku} \quad$ xílh-tal’i
FOC-3CONJ-PERC.EVID
NOM-Sylvia DET do(CAUS)-TOP
'Apparently it was Sylvia who did it.'
Consultant's comment for (b): "If you could see Sylvia hiding behind the door, you might say that."


(14) Context: You are a teacher and you come into your classroom and find a caricature of you drawn on the blackboard. You look around and you see that only one child is covered in chalk dust, Sylvia.
a. nilh $k^{\prime} a$ s-Sylvia ku xílh-tal'i
FOC INFER NOM-Sylvia DET do(CAUS)-TOP
'It must have been Sylvia who did it.'
b. nílh-as-an' s-Sylvia ku xílh-tal'i
FOC-3CONJ-PERC.EVID NOM-Sylvia DET do(CAUS)-TOP
'Apparently it was Sylvia who did it.'

Summarizing so far, we have established that all of the three clitics explicitly encode the source of the information presented in the utterance. They are classifiable within Willett's typology as listed in (15).
(15) ku7 indirect reported evidential ('reportative')
$k^{\prime} a \quad$ indirect inferring evidential ('inferential')
-an' indirect inferring evidential of result ('perceived evidence')

\section{Two approaches to evidentials}

Within the formal semantic literature, there are two prominent approaches to evidentials. The first is to analyse evidentials as epistemic modals with an extra meaning component (see for example Kratzer 1991, Izvorski 1997, Garrett 2000, Ehrich 2001, among others). The second approach is to analyse them as illocutionary operators which do not contribute to the content of the proposition 
expressed (see for example Faller 2002). Here we will provide evidence that all three of the St'át'imcets evidentials are of the epistemic modal type. However, we believe it to be established that both kinds of evidential exist in natural language: those which are epistemic modals, and those which are not. ${ }^{7}$ What is novel in the current paper is the application of a range of tests explicitly designed to test for modal status, as well as the proposal that elements can be modals without having to encode any distinctions in modal force (see sections 4 and 5 below).

In section 3.1, we outline an epistemic modal analysis of evidentials, drawing on Izvorski's (1997) analysis of the perfect of evidentiality in Bulgarian. In section 3.2 we present Faller's (2002) illocutionary operator analysis. We adopt a standard view of the semantics of modals, according to which they introduce quantification over possible worlds. See Kratzer $(1977,1981,1991)$ for the framework assumed.

\subsection{A modal analysis of evidentials}

Izvorski (1997) claims that in Bulgarian, the perfect is ambiguous between a perfect interpretation and an indirect evidential. ${ }^{8}$

\footnotetext{
${ }^{7}$ Faller notes that 'The framework of speech act theory might also prove to be the right one in analyzing evidentials in other languages, although not necessarily of evidentiality in general. It is a reasonable hypothesis that evidentiality that is encoded by markers of tense and modality can more fruitfully be analyzed within a framework such as possible world semantics, which was developed for these categories' (Faller 2002:264; cited in Lecarme 2005). See also e.g. Chung (2005) for the claim that Korean has both speech-act and non-speech-act evidentials.

${ }^{8}$ Izvorski also discusses Turkish and to a lesser extent Norwegian, which appear to have very similar constructions.
} 


$$
\begin{array}{lll}
\mathrm{Az} & \text { sâm } & \text { došal } \\
\text { I } & \text { be-1SG.PRES } & \text { come-P.PART }
\end{array}
$$

'I have come.' (perfect)

'I apparently came.' (perfect of evidentiality)

(Izvorski 1997:222)

Izvorski argues that the perfect of evidentiality (PE) introduces a universal epistemic modal. However, she also observes that (16) under its evidential meaning does not simply mean 'I must have come'. Instead, the indirect evidential has an additional meaning component beyond the necessity modal. This is illustrated in (17).

(17) Knowing how much John likes wine...

a. toy trybvada e izpil vsičkoto vino včera he must is drunk all.the wine yesterday '...he must have drunk all the wine yesterday.'

$\begin{array}{lllll}\text { b. \# } & \text { toy } & \text { izpil } & \text { vsičkoto } & \text { vino včera } \\ & \text { he } & \text { drunk-PE } & \text { all.the } & \text { wine }\end{array}$

'...he apparently drank all the wine yesterday.'

(Izvorski 1997:227)

Unlike the plain epistemic modal in (17a), the perfect of evidentiality in (17b) is only appropriate if there are observable results of John's having drunk the wine (e.g., one sees empty wine bottles). Izvorski accounts for this by analyzing the PE as asserting an epistemic modal meaning, and in addition presupposing that the speaker's evidence for the embedded proposition is indirect evidence. Note that the PE allows reportative as well as inferential interpretations. Thus, the 
presupposition is worded in terms of 'indirect evidence' generally. Izvorski's central idea is summarized in (18).

(18)

assertion: $\quad \square \mathrm{p}$, in view of the speaker's knowledge state

presupposition: $\quad$ the speaker has indirect evidence for $\mathrm{p} \quad$ (Izvorski 1997:226)

According to Izvorski, the modal base is restricted by the indirect evidence presupposition; the modal base contains only those worlds in which the available indirect evidence for $\mathrm{p}$ holds. The PE contrasts with a plain epistemic modal in that with a plain modal, the modal base is merely restricted to worlds in which the available evidence (which may be of any kind) holds. Izvorski in addition utilizes a contextually-determined ordering source, which orders the worlds in the modal base according to how closely they correspond to certain beliefs about the indirect evidence.

Izvorski's analysis is informally illustrated in (19). ${ }^{9}$ Listed under 'modal base' and 'ordering source' are the propositions which narrow down or order the set of accessible worlds respectively.

(19) Ivan izpil vsičkoto vino včera

Ivan drunk-PE all.the wine yesterday

'Ivan apparently drank all the wine yesterday.'

(Izvorski 1997:228)

a. Inferential interpretation:

Modal base: $\quad$ [There are empty wine bottles in Ivan's office\}

\footnotetext{
9 We do not go into the formal details of Izvorski's proposal, since we will be adopting a modified version of her analysis.
} 
Ordering source: \{If there are empty wine bottles in someone's office, that person has drunk the wine\}

\section{b. Reportative interpretation:}

Modal base: $\quad$ \{Mary said that Ivan drank the wine

Ordering source: \{Normally, Mary is reliable as a source of information\}

Just like ordinary epistemic modals, evidentials quantify over worlds which are compatible with some actual-world evidence. In the inferential case, this means that we quantify over worlds in which (for example) there are empty wine bottles in Ivan's office. The sentence asserts that in all worlds of this type in which also the proposition 'If there are empty wine bottles in someone's office, that person has drunk the wine' is true, Ivan drank the wine. Since the actual world is presupposed to be a world in which there are empty wine bottles in Ivan's office, the sentence makes a strong claim about the actual world: unless the actual world is excluded by the ordering source, Ivan drank the wine in the actual world. ${ }^{10}$

Now let us turn to the reportative case. As with the inferential, the accessible worlds must be those in which some actual-world evidence holds. In a reportative case, the speaker's evidence for the assertion is the fact that a report was made. Therefore, the accessible worlds in the reportative case are all those worlds in which (for example) Mary said that Ivan drank the wine. The sentence

10 Garrett (2000) makes a slightly different proposal about the semantics of evidentials in Tibetan, although still within a modal approach. Garrett argues that Tibetan indirect evidentials are 'performative epistemic modals'. McCready and Ogata (2006) present an epistemic modal analysis of evidentials in Japanese within a different (dynamic) framework. 
asserts that in all worlds of this type in which Mary is reliable, Ivan drank the wine. Since the actual world is presupposed to be a world in which Mary said that Ivan drank the wine, the sentence makes a strong claim about the actual world: unless Mary is not reliable, Ivan drank the wine in the actual world.

A consequence of this analysis of reportatives is that a reportative sentence containing an embedded proposition $\mathrm{p}$ does not mean the same thing as 'Somebody / Mary said that p.' Under the modal analysis of reportatives, the sentence presupposes the existence of some report, and asserts that $\mathrm{p}$ must be true, given that report. In a sentence containing a verb of saying, the sentence asserts that a report was made, and does not commit the speaker to any claim about the truth or otherwise of p. We will see data below that confirm this difference between reportatives and verbs of saying in St'át'imcets. ${ }^{11}$

\subsection{An illocutionary operator analysis of evidentials}

A contrasting analysis of evidentials is provided by Faller (2002) on the basis of data from Cuzco Quechua. Faller argues that the Quechua Direct and Reportative evidentials are not epistemic

\footnotetext{
${ }^{11}$ There is a non-trivial issue, both for Izvorski's analysis and for our own analysis to be presented in section 6, regarding how the content of the report is restricted. On the one hand, we cannot force the report to have exactly the same form or truth conditions as the embedded proposition in a reportative statement. On the other hand, the content of the two cannot be too disparate. For example, suppose that John has one bottle in front of him on the table and says 'I see two bottles.' And suppose that on the basis of John's statement, we infer that he is drunk. We would not be justified in using a sentence of the form 'reportedly, John is drunk', even though John's statement is the evidence which caused us to believe that John must be drunk.
} 
modals; they are not analyzable in terms of necessity or possibility, and that they do not contribute to the proposition expressed. She analyses the Direct and the Reportative markers as illocutionary operators, which modify the sincerity conditions of the speech act. They may also change the illocutionary force of the sentence from plain 'assertion' to something else.

The idea is illustrated in (20) for the Quechua Direct evidential -mi. The propositional content is p; the illocutionary force is assertion, and the sincerity condition states that the speaker believes that $\mathrm{p}$ and that that belief is justified by the speaker's having seen the event e described by p (Faller 2002:25;164). The sincerity condition results in an increase in illocutionary strength over an ordinary assertion.

$$
\begin{aligned}
& \text { Para-sha-n- } m i \\
& \text { rain-PROG-3- } m i \\
& p=\text { 'It is raining.' } \\
& \mathrm{ILL}=\operatorname{ASSERT}_{\mathrm{s}}(\mathrm{p}) \\
& \mathrm{SINC}=\left\{\mathrm{Bel}(s, p), \mathrm{EV}=\operatorname{See}\left(s, e_{p}\right)\right\} \\
& \text { STRENGTH }=+1
\end{aligned}
$$

The fact that Quechua statements containing the Direct evidential are understood as stronger than their plain counterparts is in line with their non-modal status. ${ }^{12}$ As noted by Kratzer (1991) among many others, either existential or universal modal statements are weaker than their plain counterparts.

Faller's analysis of the Quechua Reportative -si is illustrated in (21). The illocutionary force

\footnotetext{
${ }^{12}$ Quechua consultants often state that assertions containing - $m i$ are more emphatic than those without (Faller 2002:156).
} 
is that of 'presentation', and the sincerity condition says that there is some other speaker, neither the current speaker nor hearer, who asserted $\mathrm{p}$.

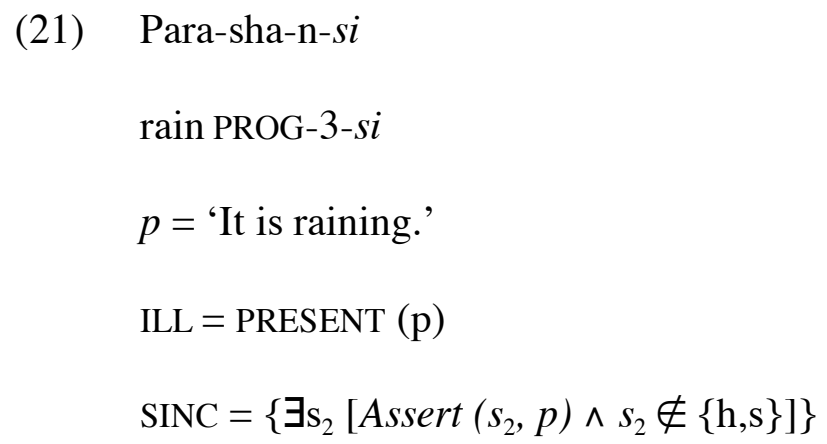

There is one evidential in Quechua, the Conjectural, which Faller analyses as involving epistemic modal semantics (as well as being an illocutionary operator, i.e. as well as introducing a sincerity condition). There is also a tense marker in Quechua which gives rise indirectly to an evidential meaning. Faller (2003) analyses the latter as being neither an illocutionary operator nor an epistemic modal; instead, it operates at the event level and locates the event outside the speaker's perceptual field at the reference time (Faller calls this marker a 'spatio-temporal operator'). We do not discuss the Quechua spatio-temporal marker here, as the St'át'imcets evidentials we are focusing on operate at the propositional level and have no relation to tense. See Faller (2003) for discussion, and see also Chung (2005) for analysis of a Korean spatio-temporal evidential. ${ }^{13}$

13 As noted in footnote 3, and as will be further discussed in 7.2, St' át'imcets also possesses a spatio-temporal adverb lákw7a with clearly evidential semantics. 


\section{The St'át'imcets evidentials are epistemic modals ${ }^{14}$}

\subsection{Predictions of the modal vs. the illocutionary operator analysis}

In this sub-section we lay out the predictions of both the modal and the illocutionary operator analysis, and in sub-section 4.2 we test the predictions.

\subsection{1 (In)felicity if embedded proposition is known to be false}

An analysis of evidentials as epistemic modals predicts that they will be infelicitous in contexts where the speaker is sure that the embedded proposition is false. This is because the speaker is asserting that the embedded proposition is possibly or necessarily true. (22) illustrates this for English epistemic modals. ${ }^{15}$

(22) \# It may/must be raining, but it is not (raining).

(Faller 2002:191)

On the other hand, the Quechua speech-act evidentials do allow the speaker to know that the

14 An earlier version of the material in this section was published in Matthewson, Rullmann and Davis (2006b); the current version is substantially revised and some new tests have been added. 15 This idea applies to the reportative case as follows. A modal statement REPORT $p$ presupposes that there is a report, and asserts that in some or all worlds in which such a report was made, $\mathrm{p}$ is true. We assume (following Faller 2002:105) that the modal base contains only worlds compatible with the speaker's knowledge. If the speaker knows that $\mathrm{p}$ is false, then the modal base contains only non-p-worlds, so the claim that some or all accessible worlds are p-worlds is not justified. See Faller (2002:105-109) for detailed discussion of the predictions of Izvorski's analysis for reportatives. 
embedded proposition is false. This follows because, for example, a reportative merely presents the embedded proposition, and has a sincerity condition stating that a third person made the relevant report. This is entirely compatible with the speaker being convinced that the embedded proposition is not true.

\subsection{2 (In)felicity if embedded proposition is known to be true}

The modal analysis predicts infelicity if the speaker knows that the embedded proposition is true.

This is firstly because the evidentials presuppose that the evidence for $\mathrm{p}$ is only indirect; this implies that the speaker cannot know for certain that $\mathrm{p}$ is true. Moreover, there will be a violation of pragmatic principles (specifically, Grice's Quantity Maxim) if a speaker who knows that p is true asserts 'possibly p' (or even 'necessarily p'), since the modal statement makes a weaker claim than the simple assertion of p. Again, this contrasts with the Quechua Direct evidential, which is as strong or stronger in its speaker-certainty level than a plain assertion.

\subsubsection{Indirect evidence requirement not cancelable}

According to the version of the modal analysis we adopt, the indirect evidence requirement is a presupposition. As noted by Izvorski (1997), this predicts that the indirect evidence requirement is not cancelable (since it is not a conversational implicature). In fact, the predictions of the two theories converge here. Recall that for Faller, the indirect evidence requirement is contained within a sincerity condition. Faller observes (2002:126) that 'sincerity conditions are not implicatures, since they cannot be canceled.'

\subsubsection{Indirect evidence requirement not blocked by negation}

The modal analysis predicts that the indirect evidence requirement projects through negation, since 
it is a presupposition. Under an illocutionary operator analysis, the evidential (as a speech-act modifier) may not take scope under any operator contained within the propositional content, including negation. The theories therefore converge in predicting that the indirect evidence requirement of an evidential behaves as if it takes wide scope with respect to negation. ${ }^{16}$

\subsubsection{Challengeability}

Next come two tests that relate to whether the evidential contributes to the truth of the proposition expressed. First is the challengeability test, which works as follows. If the relevant aspect of

16 The theories differ in whether there is also an asserted part of the semantics of the evidential, which may potentially scope under negation. Thus, the modal analysis predicts the following two potential readings for (i); the facts are that only reading (ia) is available.

$$
\begin{aligned}
& \text { aoz k'a k-wa-s } \quad \text { Sylvia ku xílh-tal'i } \\
& \text { NEG INFER DET-IMPF-3POSS Sylvia DET do(CAUS)-TOP }
\end{aligned}
$$

a. 'It is necessary that it wasn't Sylvia who did it.' [presupposition: indirect evidence]

b. 'It is not necessary that it was Sylvia who did it.' [presupposition: indirect evidence] This absence of one potential scope reading does not force us to conclude that the elements in question are not modals, since many English modals also display scope restrictions with respect to negation; see e.g., Horn (1989:259ff). Note also that de Haan's (1997) discussion of interactions with negation, in which he argues that evidentials differ from epistemic modals in taking obligatory wide scope, fails to distinguish between the restriction on the source of the information (which is predicted to take wide scope by both the modal and the non-modal analysis, and therefore does not distinguish the two) and the asserted content (which is often restricted to wide scope, even with ordinary modals). 
meaning can be questioned, doubted, rejected or disagreed with, then it forms part of the propositional content. Faller argues that while epistemic modals pass the challengeability test, the Quechua direct and reportative evidentials do not.

Faller notes that it has been claimed in some literature that epistemic modals do not contribute to the proposition expressed (e.g., by Lyons 1977, Sweetser 1990, Palmer 2001, Papafragou 2000). The examples in (23), from Papafragou (2000), are purported to demonstrate that epistemic must does not pass the challengeability test. Supposedly, (23b-d) do not challenge the epistemic claim, but rather the embedded proposition:

(23) a. Alfred must be secretly seeing Barbara.

b. Is that so?

c. I agree.

d. I don't believe it.

(Faller 2002:111)

However, Faller rightly observes that, for example, the speaker who utters (23c) in response to (23a) is not agreeing that Alfred is seeing Barbara, but rather is agreeing that Alfred must be seeing Barbara. Thus, the modal is part of the asserted propositional content (Faller 2002:112).

Further examples are given in (24-25). With either an epistemic possibility or necessity modal, B's utterance does not deny that Jo is the thief. Rather, B denies the modal claim. ${ }^{17}$ This indicates that the modal is contributing to the propositional content.

\footnotetext{
${ }^{17}$ It might seem as if in (24), B is denying that Jo is the thief, since B states that she cannot be the thief. Recall, however, that in the semantics we are assuming for modal statements, $\neg \backslash p$ does not entail $\neg$ p. B is asserting that there are no worlds compatible with what s/he knows that are
} 
(24) A: Jo could be the thief.

B: That's not true. She cannot be the thief. She would never do something like this.

(Faller 2002:113)

(25) A: Jo must be the thief.

B: That's not true. There are some other plausible suspects. Jo may be entirely innocent.

Faller argues that a hearer usually disagrees with modal statements by disagreeing with one or more of the propositions which narrow down the set of worlds in the modal base. That is, the disagreement is with the premises used by the speaker, rather than with the logical relation that the speaker claims holds between the premises and the embedded proposition. Her example is:

(26) A: If it's snowing down here, Truckee must be buried in snow.

B: That's not true. A hundred years or so ago, it snowed down here, but not a single flake in Truckee. So, it could well be that it's not snowing now in Truckee at all.

(Faller 2002:112)

The respondent in (26) is not denying that it is snowing in Truckee; thus, she is not denying p. What she is denying is the premise If it is snowing down here, it is snowing in Truckee.

Von Fintel (2005) also discusses this issue, and similarly concludes that epistemic modals do contribute to truth conditions. He suggests (following work by Mandy Simons) that sentences

stereotypical and in which Jo is the thief. However, if the actual world is non-stereotypical in some way, Jo might be the thief in the actual world. See Faller (2002:113, fn 18) for discussion. 
containing epistemic modals may contain two speech acts. The first involves the standard truthconditional semantics for epistemic modality (asserting that it is either a necessity or a possibility that $\mathrm{p}$ holds, given the available evidence). The second may consist of an assertion of $\mathrm{p}$ with a lack of conviction, or advice not to overlook the possibility that $\mathrm{p}$ holds. Von Fintel claims that hearers can respond by targeting either the epistemic claim or the embedded proposition. His example is as follows: Imagine a game of Mastermind between me and my son. ${ }^{18}$ After some rounds where I give him some hints about the solution, he says:

(27) There might be some reds.

Possible responses include:
a. That's right. There might be.
b. That's right. There are.
c. That's wrong. There can't be.
d. That's wrong. There aren't.

Responses (28a) and (28c) agree with or deny the modal claim, not merely the embedded proposition. This is evidence that the modal contributes to the propositional content of (27). The modal analysis of evidentials therefore predicts that they should behave like ordinary modals in allowing challenges or agreements with the modal claim or with the premises which narrow down

\footnotetext{
${ }^{18}$ Mastermind is a game in which one player places coloured pegs behind a screen and the other must work out the colours and the order of the pegs after eliciting some clues.
} 
the modal base. Of course, the illocutionary operator analysis of evidentials predicts that they do not contribute to the proposition expressed and therefore will not pass the challengeability test.

\subsubsection{Embedding}

The second test relating to whether evidentials contribute to the truth of the proposition expressed involves embedding. The idea is that an illocutionary operator cannot be embedded, but an element that contributes to the proposition expressed should be able to be embedded. Two core constructions which are expected not to allow illocutionary operators are the antecedent of a conditional, and under a factive attitude verb or verb of saying. For example, (29) shows that illocutionary adverbials such as frankly are not embeddable, while reportedly and obviously are.

(29) a. If John's book has frankly sold very little, you shouldn't be surprised.

b. If the ball was reportedly over the line, the matter should be investigated further.

c. If the cook obviously won't poison the soup, we can eat the meal without worrying.

(Faller 2002: 216; data from Ifantidou-Trouki 1993)

In (29a), the addressee is instructed not to be surprised if John's book has sold very little - not if the speaker is frank when saying the sentence. The meaning of frankly is not embeddable (and the sentence is, in our judgement, somewhat degraded). In (29b), on the other hand, the matter should be investigated if the ball is reported to be over the line; the requirement is not that the ball be over

the line before an investigation is warranted. Similar results obtain for (29c) with obviously. ${ }^{19,20}$

19 Faller notes that the embedding tests are slightly problematic. Firstly, the data are disputed for epistemic modals. For example, Papafragou (2000) claims that epistemic modals are not 


\subsubsection{Summary}

The predictions for each theory are summarized in (30).

\begin{tabular}{|c|c|c|c|}
\hline \multicolumn{2}{|c|}{ (30) } & modal analysis & illoc. operator \\
\hline 1. & felicitous if $\mathrm{p}$ is known to be false? & no & yes \\
\hline 2. & felicitous if $\mathrm{p}$ is known to be true? & no & yes \\
\hline 3. & indirect evidence requirement cancelable? & no & no \\
\hline 4. & indirect evidence requirement blocked by negation? & no & no \\
\hline 5. & challengeable? & yes & no \\
\hline 6. & embeddable? & yes & no \\
\hline
\end{tabular}

\subsection{Testing the predictions in St'át'imcets}

\subsection{1 (In)felicity if embedded proposition is known to be false}

embeddable, but Faller (2002:213-214, 217) gives data suggesting that they are. Furthermore, the test is only valid in one direction. Elements which can embed clearly contribute to the proposition expressed; however, if an element cannot embed, we cannot automatically conclude that it does not contribute to the proposition expressed, since there may be some independent reason why it cannot be embedded under certain circumstances.

20 There is one further test used by Faller, that of whether evidentials give rise to an ambiguity in content questions (Faller 2002:229ff). We do not discuss this test here, as we have so far found it impossible to elicit helpful or consistent judgements about evidentials in content questions. 
The St'át'imcets evidentials are not felicitous if the speaker is sure the embedded proposition is false. In this respect, they behave like modals. This is shown in (31-2) for the inferential evidentials.

$\begin{array}{llllll}\text { (31) * wa7 k'a kwis, t'u7 aoz t'u7 } & \text { k-wa-s } & \text { kwis } \\ \text { IMPF INFER rain but NEG just } & \text { DET-IMPF-3POSS } & \text { rain } \\ \text { 'It may/must be raining, but it's not raining.' } & \end{array}$

$\begin{array}{llllll}\text { (32) * wá7-as-an' } & \text { kwis, t'u7 } & \text { aoz } & \text { t'u7 } & \text { k-wa-s } & \text { kwis } \\ \text { IMPF-3CONJ-PERC.EVID } & \text { rain } \quad \text { but } \quad \text { NEG } & \text { just } & \text { DET-IMPF-3POSS } & \text { rain } \\ \text { 'It's apparently raining, but it's not raining.' } & & & \end{array}$

Consultant's comment: "It's contradictory."

For the reportative evidential, (33-4) show that whether or not the source of the report is perceived to be reliable, reportative statements are always infelicitous if the speaker knows the embedded proposition to be false. (34) is adapted from similar data (with different results) given in Faller (2002); see (36) below.

(33) Context: Your husband always tells the truth; he is very reliable, and he also tries never to say things unless he knows for sure they are true. So when he says things, you always believe him. However, this time you know he was mistaken. Someone was injured at the Country Store and you know for sure it was Maria, because you were there when it happened and you saw it. You also know that Julia wasn't injured because you just saw Julia and she was not injured. But your husband misunderstood the story when he heard it, 
and he thinks it was Julia who was injured. Your husband comes home and tells you 'xan' kw sJulia láku7 Country Storeha lhkúnsa ku sq'it’ ('Julia was injured at the Country Store today'). Then, when you see me later that evening, you say:

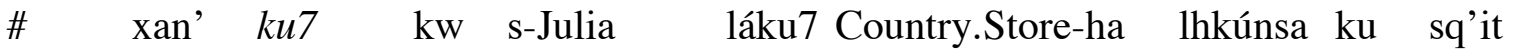
hurt REPORT DET NOM-Julia DEIC Country.Store-DET now DET day '[I was told] Julia was injured at the Country Store today.'

Consultant's comment: "Okay if you add something like tsut nkwtámtsa [my husband said] at the end."

(34) Context: You had done some work for a company and they said they put your pay, $\$ 200$, in your bank account. but actually, they didn't pay you at all.

* um'-en-tsal-itás $\quad k u 7 \quad$ i án’was-a xetspqíqen'kst táola, give-DIR-1SG.OBJ-3PL.ERG REPORT DET.PL two-DET hundred dollar

$\begin{array}{lllll}\text { t'u7 } & \text { aoz } & \text { kw } & \text { s-7um'-en-tsál-itas } & \text { ku stam' } \\ \text { but } & \text { NEG } & \text { DET } & \text { NOM-give-DIR-15.OBJ-3P.ERG } & \text { DET what }\end{array}$

'They gave me $\$ 200$ [I was told], but they didn't give me anything.'

Corrected to:

\begin{tabular}{llllll} 
tsút-wit & \multicolumn{1}{c}{ kw } & \multicolumn{1}{c}{ s-7um'-en-tsal-itás } & ku7 & $\mathrm{i}$ \\
say-3PL & DET & NOM-give-DIR-1SG.OBJ-3PL.ERG & REPORT & DET.PL \\
án'was-a & xetspqíqen'kst & táola $\ldots$ & & \\
two-DET & hundred & dollar ... & &
\end{tabular}

'They SAID they gave me $\$ 200 \ldots$... 
The St'át'imcets evidentials contrast in this respect with the Quechua illocutionary operator evidentials. The latter $d o$ allow the speaker to know that the embedded proposition is false. This is illustrated in (35-6). ${ }^{21}$

$$
\begin{aligned}
& \text { para-sha-n-si, ichaqa mana crei-ni-chu } \\
& \text { rain-PROG-3-sibut not believe-1-NEG } \\
& \mathrm{p}=\text { 'It is raining, but I don't believe it.' } \\
& \mathrm{EV}=\text { speaker is/was told that it is raining }
\end{aligned}
$$

$$
\begin{aligned}
& \text { Pay-kuna-s ñoqa-man-qa qulqi-ta muntu-ntin-pi saqiy-wa-n, } \\
& \text { (s)-he-PL-si I-ILLA-TOPmoney-ACC lot-INCL-LOC leave-1O-3 } \\
& \text { mana-máriki riku-sqa-yui ni un sol-ta centavo-ta-pis } \\
& \text { not-SURPright see-PP-2 not one sol-ACC cent-ACC-ADD } \\
& \text { saqi-sha-wa-n-chu } \\
& \text { leave-PROG-10-3-NEG }
\end{aligned}
$$

'They left me a lot of money, but, as you have seen, they didn't leave me one sol, not one cent.'

EV = It is said/They said that they left me a lot of money.' $\quad$ (Faller 2002:191)

\footnotetext{
${ }^{21}$ In this respect, the Quechua reportative patterns like an overt verb of saying: in both English and St'át'imcets, it is fine to say 'They said it is raining, but I don't believe it.' Recall that the modal analysis clearly differentiates a reportative from a verb of saying. A verb of saying asserts that a certain report was made, and makes no claim about the truth or falsity of that report. A modal reportative presupposes that a report was made, and asserts that the report was at least possibly true.
} 


\subsection{2 (In)felicity if embedded proposition is known to be true}

The St'át'imcets evidentials are not felicitous if the speaker is sure that the embedded proposition is true. This is shown in (37-42); the reportative data in (41-2) include a case where the source is reliable, and a case where the source is unreliable. These data support a modal analysis of the St'át'imcets evidentials.

$\begin{array}{ccccc}\text { * ts'um'-qs-án'-as } \quad k^{\prime} a & \text { kw } & \text { s-Lémya7 } & \text { kw } & \text { s-Roger; } \\ \text { lick-nose-DIR-3ERG INFER } & \text { DET NOM-Lémya7 } & \text { DET } & \text { NOM-Roger } \\ \text { ats'X-en-lhkán } & \text { wi7 } & \text { zam' } & \\ \text { see-DIR-1SG.SUBJ } & \text { EMPH } & \text { after.all } & \end{array}$

'Lémya7 must have kissed Roger; actually I saw it.'

Consultant's comment: "You're guessing but you're saying you saw it."

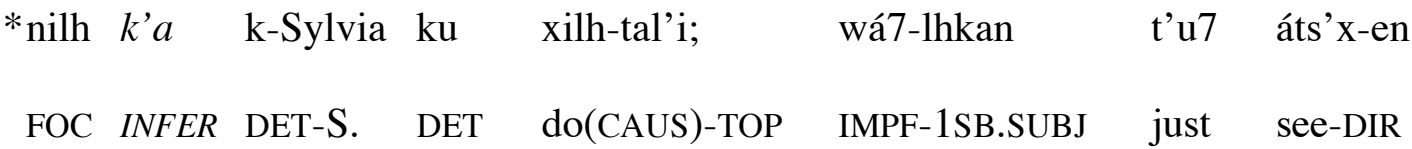
'It must have been Sylvia who did it; I saw her.'

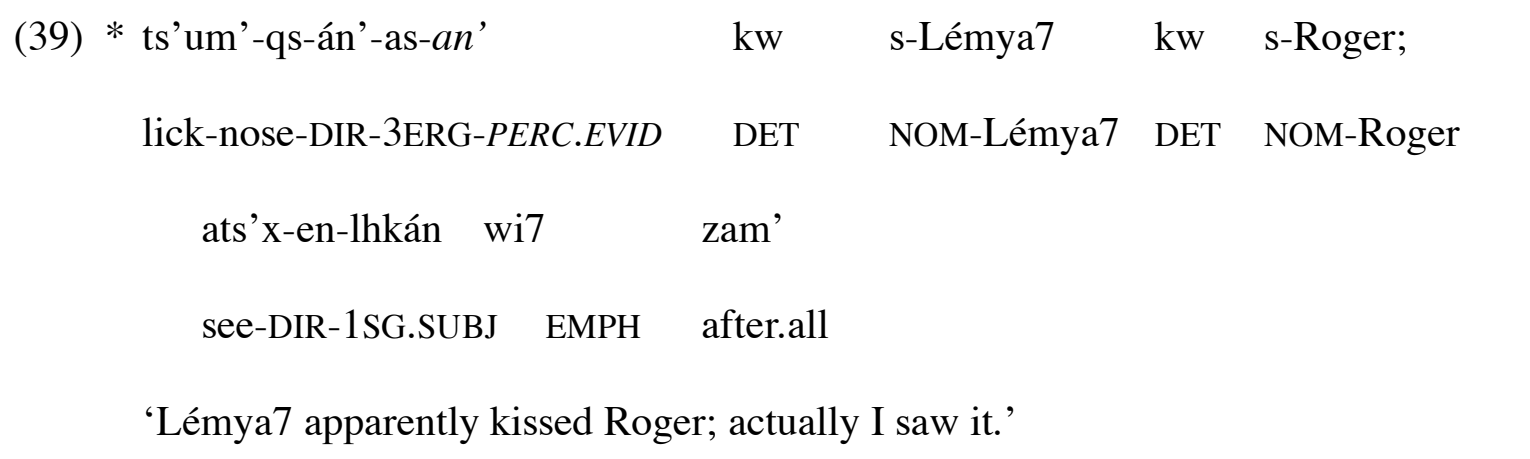


(40)

*nilh-as-an' $\quad$ k-Sylvia $\quad$ ku $\quad$ wa7 $\quad$ xílh-tal'i; $\quad$ wá7-lhkan $\quad$ t’u7 FOC-3CONJ-PERC.EVID DET-Sylvia DET IMPF do(CAUS)-TOP IMPF-1SB.SUBJ just áts’x-en see-DIR

'It was apparently Sylvia who did it; I saw her.'

(41) Context: You were invited to Ted's wedding and you went there and watched him get married. Marilyn (Ted's sister) didn't see you at the wedding and didn't know you had been invited. She told you 'Ted got married.' Later, you see me and you tell me:

\# $\quad$ melyíh $\quad k u 7 \quad$ kw $\quad$ s-Ted marry $\quad$ REPORT DET NOM-Ted '[I heard] Ted got married.'

(42) Context: You were invited to Ted's wedding and you went there and watched him get married. Henrietta (Ted's other sister) didn't see you at the wedding and didn't know you had been invited. Henrietta has a reputation for being unreliable and often lying. She told you 'Ted got married.' Later, you see me and you tell me:

\# $\quad$ melyíh $\quad k u 7 \quad$ kw $\quad$ s-Ted

marry REPORT DET NOM-Ted

'[I heard] Ted got married.'

\subsubsection{Indirect evidence requirement not cancelable}

Recall that neither the modal analysis nor the illocutionary force analysis predicts that the indirect evidence requirement can be canceled. The data in (37-40) above already showed that the indirect 
evidence requirement cannot be canceled for inferential $k^{\prime} a$ or for perceived-evidence -an'. Parallel sentences are given in (43-4) for reportative $k u 7$.

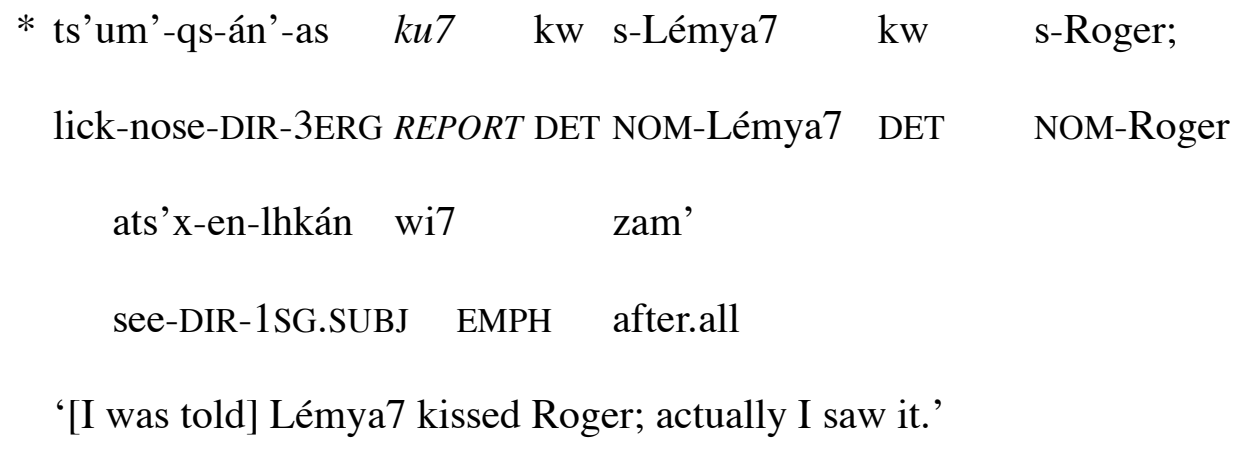

(44) *nilh ku7 k-Sylvia ku wa7 xílh-tal'i; wá7-lhkan t'u7 áts'x-en FOC REPORT DET-Sylvia DET IMPF $\quad$ do(CAUS)-TOP IMPF-1SB.SUBJ just $\quad$ see-DIR '[I was told] it was Sylvia who did it; I saw her.'

Consultant's comment: “ $k u 7$ means somebody told you, you didn't see it.”

\subsubsection{Indirect evidence requirement not blocked by negation}

Here again, both approaches make the same prediction, namely that the requirement for indirect evidence will still obtain in negative contexts. This is correct for the St'át'imcets evidentials. First, though, we need to clarify the predicted readings (see also footnote 16). We use an example of Izvorski's, given in (45):

$$
\begin{aligned}
& \text { Ivan ne izkaral izpita } \\
& \text { Ivan not passed-PE the-exam } \\
& \text { = 'Ivan didn't pass the exam (it is said/I infer).' }
\end{aligned}
$$


$\neq$ 'It is not the case that $\{$ it is said/I infer $\}$ that Ivan passed the exam.'

(Izvorski 1997:228)

Izvorski uses (45) as an argument that the indirect evidence requirement of the PE does not disappear under negation and therefore is a presupposition. Under an analysis of the PE as a necessity modal, (45) should actually have two readings, depending on the scope of the modal with respect to negation. This is independent of the inability of the indirect evidence requirement to be negated. We might expect both the readings informally summarized in $(46 a, b)$ to be available. We do not expect the reading in $(46 \mathrm{c})$.

(46) a. It is not the case that in all accessible worlds, Ivan passed the exam.

[allows Ivan to pass in some accessible worlds]

[presupposes speaker has indirect evidence for the modal claim]

b. In all accessible worlds, it is not the case that Ivan passed the exam.

[Ivan fails in all accessible worlds]

[presupposes speaker has indirect evidence for the modal claim]

c. It is not the case that I have indirect evidence that in all accessible worlds, Ivan passed the exam.

[can be understood as denying that speaker's evidence is indirect]

Based on the translations given by Izvorski in (45), it appears that the Bulgarian PE sentence has only reading (46b). This result is consistent with the modal analysis. An extra explanation would 
need to be offered about why (46a) is absent. However, such restrictions on available scope relations between modals and negation are attested in English and other languages; see for example Horn (1989), and the data in (47):
a. Harriet should not leave.
$\forall \neg ; * \neg \forall$
b. Harriet must not leave.
$\forall \neg ; * \neg \forall$
c. Harriet will not leave.
$\forall \neg ; * \neg \forall$
d. Harriet would not leave.
$\forall \neg ; * \neg \forall$

The same results hold for the St'át'imcets evidentials, as shown in (48-50). The negation cannot be construed as negating the indirect status of the evidence, but the modal itself has unambiguously high scope with respect to negation.

$$
\begin{aligned}
& \text { aoz } k \text { 'a k-wa-s Sylvia ku xílh-tal'i } \\
& \text { NEG INFER DET-IMPF-3POSS Sylvia DET do(CAUS)-TOP } \\
& =\text { '[I have indirect evidence that }] \text { It wasn't Sylvia who did it.' } \\
& \neq \text { 'It is not the case that I have indirect evidence that Sylvia did it.' }
\end{aligned}
$$

$$
\begin{aligned}
& \text { cw7áoz-as-an' } \quad \text { kw } \quad \text { s-nilh-ts } \quad \text { s-Sylvia } \quad \mathrm{ku} \quad \text { xílh-tal'i } \\
& \text { NEG-3CONJ-PERC.EVID DET NOM-FOC-3POSS NOM-Sylvia DET do(CAUS)-TOP } \\
& \text { '[I have indirect perceived evidence that }] \text { It wasn't Sylvia who did it.' } \\
& \text { \# 'I don't have indirect perceived evidence that it was Sylvia who did it.' }
\end{aligned}
$$


(50)

$\begin{array}{lccccc}\text { cw7aoz } & k u 7 & \text { séna7 } & \mathrm{ku} & \mathrm{qu} 7 & \text { láti7 } \\ \text { NEG } & \text { REPORT } & \text { COUNTER } & \text { DET } & \text { water } & \text { DEIC } \\ =\text { '[I was told }] \text { There was no water there.' } \\ \text { F'I was not told that there was water there.' }\end{array}$

(Matthewson 2005:389)

For the attempted second reading of (50), the consultant corrects the sentence to (51), which contains an explicit verb of saying.

\begin{tabular}{|c|c|c|c|c|c|c|}
\hline cw7aoz & $\mathrm{kw}$ & sqwal'-en-tsál-em & $\mathrm{kw}$ & s-wá7 & láti7 & $\mathrm{ku}$ \\
\hline NEG & DET & tell-DIR-1SG.OBJ-PASS & DET & NOM-be & DEIC & DET \\
\hline pún- & lhkan & s7éntsa & & & & \\
\hline find ( & DIR)- & 1SG.EMP & & & & \\
\hline
\end{tabular}

'I wasn't told that there was water there; I found it myself.'

In summary, the requirement for indirect evidence is not blocked by negation; this is consistent with its status as a presupposition. ${ }^{22}$

22 Faller notes that presuppositions are blocked if the presupposition trigger appears in the consequent of a conditional whose antecedent explicitly contains the presupposition. For example, (ia) presupposes (ib), but (ic) does not presuppose (ib).

(i) a. John will stop smoking when he reads this.

b. John currently smokes.

c. If John smokes, he will stop smoking when he reads this. (Faller 2002:118)

Faller therefore argues that an element whose evidential meaning was a presupposition should lose 
its evidential meaning in cases parallel to (ic). To show that this is not the case for the Quechua reportative, Faller gives the example in (ii). She observes that '[i]n as much as the statement in (ii) makes any sense at all, it is clear that the evidential meaning of -si in the consequent is not cancelled by expressing it explicitly in the antecedent.'

$$
\begin{aligned}
& \text { sichus ni-wa-rqa-n Juan hamu-na-n-ta chay-qa, Juan-qa hamu-nqa-s } \\
& \text { if say-1O-PST1-3 Juan come-NMLZ-3-ACC this-TOP, Juan- TOP come-3FUT-si } \\
& \mathrm{p}=\text { 'If I was told that John will come, then John will come.' }
\end{aligned}
$$$$
\mathrm{EV}=\text { speaker was told that Juan will come.' }
$$

Corresponding data have been difficult to elicit in St'át'imcets, since the sentences sound bizarre to consultants. However, we argue that even if the evidential meaning is preserved in the consequent of examples such as (ic,ii), this does not necessarily constitute evidence against the presuppositional analysis of the evidential requirements. Notice that other grammatical elements which are frequently analyzed as inducing presuppositions also retain their presuppositions in parallel contexts. This is illustrated in (iii) for the gender features of pronouns. The pronoun in the second clause is still interpreted with its usual gender restrictions.

(iii) If the teacher is female, then she can coach the girls' basketball team.

A similar response can be given to another potential argument against the presuppositional analysis of evidential meanings. Martina Faller (p.c.) points out that evidential presuppositions are unusual in that they must almost always induce accommodation. When one uses an evidential, one typically does not expect the hearer to already know the nature of the evidence. However, the evidential presuppositions again parallel the presuppositions of tense and pronoun features here. Hearers must very often accommodate the temporal presuppositions of tense morphemes or the gender or the number presuppositions of pronouns. 


\subsubsection{Challengeability}

The challengeability facts support a modal analysis of the St'át'imcets evidentials. Data for $k^{\prime} a$ and -an' are given in (52-5). In (52) and (53), we see that the hearer can challenge the premises used by the speaker (i.e., part of the ordering source). In neither of these cases does B deny the embedded proposition $\mathrm{p}$.

(52) Context: A is driving past John's house with B and sees John's lights are on.

A: wá7 k’a 1-ta tsítcw-s-a s-John; tákem i sts’ák’w-s-a be INFER in-DET house-3POSS-DET NOM-John all DET.PL light-3POSS-DET

$$
\begin{array}{ll}
\text { wa7 s-gwel } & \text { STAT-burn }
\end{array}
$$

'John must be home; all his lights are on.'

B: aoz kw-a-s wenácw; papt wa7 lháp-en-as kw-a-s

NEG DET-IMPF-3POSS true always IMPF forget-DIR-3ERG DET-IMPF-3POSS

$$
\text { lháp-an'-as } \quad \text { i } \quad \text { sts'ák'w-s-a lh-as } \quad \text { úts'qa7 }
$$

put.out-DIR-3ERG DET.PL light-3POSS-DET when-3CONJ go.out

'That's not true. He always forgets to turn his lights off when he goes out.'

B's statement $\neq \quad$ 'John is not home.'

B's statement $=\quad$ 'It is not true that John must be home.'

B denies the premise: If John's lights are on, he is home.

(53) Context: A is driving past John's house with B and sees John's lights are on. 
A: wá7-as-an' l-ta tsítcw-s-a s-John; tákem

be-3CONJ-PERC.EVID in-DET house-3POSS-DET NOM-John all

$\begin{array}{lll}\text { i } \quad \text { sts'ák'w-s-a } & \text { wa7 } & \text { s-gwel } \\ \text { DET.PL light-3POSS-DET } & \text { IMPF } & \text { STAT-burn }\end{array}$

'Looks like John is home; all his lights are on.'

B: aoz kw-a-s wenácw; papt wa7 lháp-en-as kw-a-s

NEG DET-IMPF-3POSS true always IMPF forget-DIR-3ERG DET-IMPF-3POSS

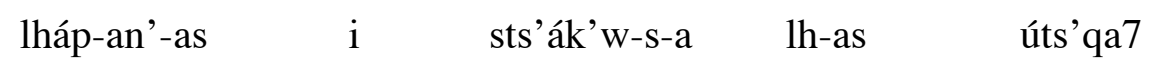
put.out-DIR-3ERG DET.PL light-3POSS-DET when-3CONJ go.out

'That's not true. He always forgets to turn his lights off when he goes out.'

B's statement $\neq \quad$ 'John is not home.'

B's statement $=\quad$ 'It is not true that John must be home.'

B denies the premise: If John's lights are on, he is home.

The Mastermind examples are given in (54-5); the results are almost the same as in English. The St'át' imcets speakers do not much like responses of the form 'yes, there might be' or 'no, there can't be' in this context (see footnotes 23 and 24). However, this is not because they are unable to challenge the modal claim, but rather because in the Mastermind example, the responder is in possession of all the facts. Therefore, it is felt to be misleading to make a modal assertion instead of a plain assertion. However, once it is explained to the consultants that in this context, the responder is trying not to reveal the answer to the problem, but rather to confirm or disconfirm the son's modal hypothesis, the relevant sentences are accepted. These data therefore support the claim that 
the St'át'imcets evidentials contribute to the proposition expressed in the same way that English epistemic modals do.

(54) Context: Imagine a game where someone places some different coloured pegs behind a screen and the other person has to guess the colours and the order after getting some clues. After some rounds where I give my son some hints about the solution, he says:

wá7 $\quad k^{\prime} a \quad$ i $\quad$ tseqwtsíqw-a

be INFER DET.PL red-DET

'There might be some reds.'

Possible responses include:

a. wenácw; wá7 k’a

true be INFER

'That's right. There might be.'23

b. wenácw; wá7

true be

'That's right. There are.'

\footnotetext{
${ }^{23}$ The consultant's initial response to (54a) was "You know, so you can't really say $k$ ' $a$." Once the context was more fully explained, she commented "It's okay, if you don't want to let him know."
} 

c. aoz kw-a-s
wenácw
aoz k’a kw s-wá7
NEG DET-IMPF-3POSS
true
NEG INFER DET NOM-be

'That's wrong. There can't be.'

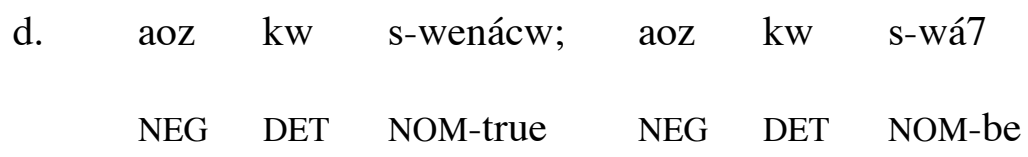

'That's wrong. There aren't.'

(55) Same context as above.
wá7-as-an' i tsequtsíqw-a
be-3CONJ-PERC.EVID DET.PL red-DET

'There might be some reds.'

Possible responses include:
a. wenácw; wá7-as-an'
true be-3CONJ-PERC.EVID
'That's right. There might be. ${ }^{24}$

\footnotetext{
${ }^{24}$ One consultant freely accepted (55a). A second consultant's initial response to (55a) was "You wouldn't say wá7asan' because then you would be guessing." When asked whether it would it be okay if the responder is trying not to let the son know the facts, but merely wants to say "You're right, there might be," the consultant accepted the sentence. This second consultant also displayed the same initial reluctance to accept (55c).
} 
b. wenácw; wá7

true be

'That's right. There are.'

$\begin{array}{lllll}\text { c. aoz } & \text { kw } & \text { s-wenácw; } & \text { áoz-as-an' } & \text { s-wá7 }\end{array}$

NEG DET NOM-true NEG-3CONJ-PERC.EVID DET NOM-be

'That's wrong. There can't be.'

d. aoz kw s-wenácw; aoz kw s-wá7

NEG DET NOM-true NEG DET NOM-be

'That's wrong. There aren't.'

Challengeability data for the reportative are given in (56). Here, the second speaker challenges the restriction on the ordering source that says the source of the report is reliable.

(56) Context: Josie is a liar; she always lies and never tells the truth. You never believe what she says. Yesterday, you heard Josie telling me that Roger was elected chief. Then today, you hear me telling someone else:

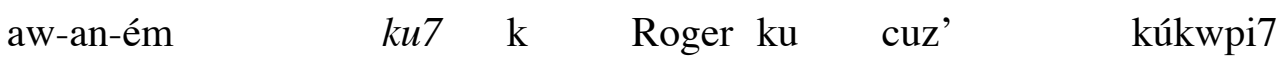

choose-DIR-1PL.ERG INFER DET Roger DET going.to chief

'[I was told] We chose Roger to be the chief.'

You say to me: 


$\begin{array}{lllll}\text { kánem s-tsút.-su } & \text { áti7? } & \text { kakez7-úlh } & \mathrm{k} & \text { Josie } \\ \text { why NOM-say-2SG.POSS } & \text { DEIC } & \text { lie-always } & \text { DET } & \text { Josie }\end{array}$

'Why do you say that? Josie is a liar.'

To conclude this section, we can contrast the possibility of challenging the modal claim of the evidentials (as in (52-6)) with the impossibility of challenging the indirect evidence requirement. The latter can not be challenged, because it is a presupposition rather than part of the asserted content. ${ }^{25}$

Context: Your car was stolen.

\begin{tabular}{|c|c|c|c|c|c|c|}
\hline \multirow[t]{2}{*}{ A: } & nilh & $k u 7$ & s-Bill & ta & naq'w-ens-táli-ha & n-káoh-a \\
\hline & FOC & REPORT & NOM-Bill & DET & steal-DIR-TOP-DET & 1SG.POSS-car-DET \\
\hline
\end{tabular}

25 Faller (2002:157-158) tests challengeability for the Quechua Direct evidential - mi by testing whether the requirement that the speaker have the best possible grounds for the statement can be challenged. For example, if a speaker says 'Ines visited her sister yesterday' using the Direct evidential, the hearer may not reply 'That's not true. You didn't see this.' However, the inability to challenge the indirect evidence requirement using 'That's not true' is predicted under either the modal approach or the illocutionary operator approach. Similarly, in Faller's discussion of the Reportative -si (2002:195-196), she shows that the requirement for a report cannot be canceled, but does not show whether the modal claim predicted by an Izvorski-style analysis can be canceled. 


$\begin{array}{ccccccc}\text { B: } \quad \text { aoz } & \text { kw } & \text { s-wenácw; } & \text { plan-lhkacw } & \text { lháp-en } & \text { kw } & \text { s-7áts'x-en-acw } \\ \text { NEG } & \text { DET } & \text { NOM-true } & \text { already-2S.SUBJ } & \text { forget-DIR } & \text { DET } & \text { NOM-see-DIR-2S.CONJ } \\ & \text { ta } & \text { káoh-sw-a } & \text { láku7 } & \text { tsítcw-s-a } & \text { s-Bill } \\ & & & & & \\ & \text { DET } & \text { car-2SG.POSS-DET } & \text { DEIC } & \text { house-3POSS-DET } & \text { NOM-Bill }\end{array}$

'That's not true. You forgot you already SAW your car at Bill's house.'

Consultant's comment (looks confused): "He didn't take it, but the car was over at his house?!”

The consultant's response to (57) demonstrates that she understands B's statement 'That's not true' as denying A's claim that Bill stole the car. Crucially, the consultant is unable to understand B as denying the indirect evidence requirement of A's evidential. A similar example is given in (58).

Context: Your car was stolen.

\begin{tabular}{|c|c|c|c|c|c|c|}
\hline \multirow[t]{2}{*}{ A: } & nilh & $k u 7$ & s-Bill & $\mathrm{ti}$ & naq'w-ens-táli-ha & n-káoh-a \\
\hline & FOC & REPORT & NOM-Bill & DET & steal-DIR-TOP-DET & 1SG.POSS-car-DET \\
\hline
\end{tabular}

B: \# aoz kw s-wenácw; plan-lhkacw lháp-en kw s-7áts'x-en-acw NEG DET NOM-true already-2S.SUBJ forget-DIR DET NOM-see-DIR-2S.CONJ

$\begin{array}{lllll}\text { s-Bill } & \text { i } & \text { naq'wensas } & \text { ti } & \text { káoh-sw-a } \\ \text { NOM-Bill } & \text { when.PAST } & \text { steal-DIR-3ERG } & \text { DET } & \text { car-2SG.POSS-DET }\end{array}$

'That's not true. You forgot you SAW Bill steal your car.' 
Consultant's comment (looks confused): “I don't know! Bill DID steal the car, didn't he? so why is that other person denying it?"

\subsubsection{Embedding}

The embedding data show that the St'át'imcets evidentials do not behave like illocutionary operators. We begin with reportative $k u 7$. This has two readings when it is embedded under verbs of saying. It may either merely reinforce the matrix verb of saying (cf. Portner's 1997 'moodindicating' modals in English), or it may be semantically embedded (in which case it was the embedded subject who heard about the proposition from someone else). Examples of each are given in (59) and (60) respectively. Note that the issue here is not one of relative scope between the evidential and the attitude verb. The contrast here is between an essentially meaningless (or reinforcing) use of the modal (59), as opposed to a true embedded reading (60). It is the latter reading which provides evidence against an illocutionary operator analysis.

(59) a. Context: Lémya7 saw Mary at the bank and Mary was obviously pregnant. Later, Lémya7 told you that Mary was pregnant. You yourself haven't seen Mary yet. Then you tell me:

tsut $\quad$ kw $\quad$ s-Lémya7 kw $\quad$ sqwemémn'ek $\quad k u 7 \quad$ s-Mary say DET NOM-Léya7 DET pregnant REPORT NOM-Mary 'Lémya7 said that Mary is pregnant.' [speaker was told by Lémya7; Lémya7 witnessed it; $k u 7$ merely reinforces the matrix verb of Lémya7's saying] 
$\begin{array}{llllll}\text { b. } & \text { wa7 tu7 } & \text { tsun-tumúl-itas } & \text { kw } & \text { s-wá7 } & k u 7\end{array}$

IMPF then Say(DIR)-1PL.OBJ-3PL.ERG DET NOM-be REPORT cw7it láti7 i ámh-a melk many DEIC DET.PL good-DET milk

'They told us that there was lots of good milk there.'

[We were told by them; they witnessed it; $k u 7$ merely reinforces matrix verb of telling]

(Matthewson 2005:204)

$\begin{array}{lllllll}\text { c. tsut } & \mathrm{kw} & \text { s-ats'x-en-ás } & k u 7 & \mathrm{ku} & \text { wa7 } & \text { 'sasquatch' } \\ \text { say } & \text { DET } & \text { NOM-see-DIR-3ERG } & \text { REPORT } & \text { DET } & \text { IMPF } & \text { sasquatch }\end{array}$

'He said he saw a sasquatch.'

[speaker was told by him; he witnessed it; $k u 7$ merely reinforces matrix verb of saying] (adapted from Matthewson 2005:416)

(60) a. tsut $\mathrm{kw}$ s-Lémya7 kw s-melyíh ku7 ta í7mats-s-a s-Rose say DET NOM-L. DET NOM-marry REPORT DET grandchild-3POSS-DET NOM-R. 'Lémya7 said that [she was told that] Rose's grandchild got married.' [Lémya7 was told; Lémya7 did not witness it; $k u 7$ relates to the report given to Lémya7]

Consultant's comment: "Lémya7 was saying that and she wasn't there either."

b. tsut s-Lémya7 kw sqwemémn'ek $k u 7$ s-Mary, t’u7 plán-lhkan ti7 say NOM-L. DET pregnant REPORT NOM-M. but already-1SG.SUBJ DEM 


$$
\begin{aligned}
& \text { zwát-en - áts'x-en-lhkan s-Mary áta7 tecwp-álhcw-a inátcwas } \\
& \text { know-DIR see-DIR-1SG.SUBJ NOM-M. DEIC buy-place-DET yesterday }
\end{aligned}
$$

'Lémya7 said that [she was told that] Mary is pregnant, but I already knew that; I had seen Mary at the store.'

[Lémya7 was told; Lémya7 did not witness it; $k u 7$ relates to the report given to Lémya7]

St'át'imcets $k u 7$ contrasts in its ability to be embedded with the Quechua reportative $-s i$, which cannot scope under a verb of saying, as shown in (61). (61ii) corresponds to the "moodindicating' reading, and (61iii) to the embedded reading.

$$
\begin{aligned}
& \text { Marya ni-wa-rqa-n Pilar- }\left({ }^{*} s i\right) \quad \text { chayamu-sqa-n-ta-s } \\
& \text { Marya say-10-PAST1-3 Pilar arrive-PP-3-ACC-si }
\end{aligned}
$$
(i) speaker was told by someone else that Marya told the speaker that Pilar arrived
(ii) speaker was told by Marya that Pilar arrived
(iii) $\quad \neq$ Marya was told that Pilar arrived
(Faller 2002:222)

The St'át'imcets inferential k'a, like $k u 7$, also has not only reinforcing (or 'mood-indicating' readings, as in (62), but crucially also embedded readings, as in (63).

(62) Context: Your small nephew comes running up to you and tells you that his sister punched him in the face. He has a red mark on his face, and you notice that the sister is looking 
guilty. You tell the kids' mother what happened and she says she doesn't believe it, because her daughter never punches people. You say:

\begin{tabular}{|c|c|c|c|c|c|}
\hline wenácw-nun'-lhkan & $\mathrm{kw}$ & s-tup-un'-ás & $k^{\prime} a$ & ta & n-sqwsés7-a, \\
\hline true-DIR-1SG.SUBJ & DET & NOM-punch-DIR-3ERG & INFER & DET & 1SG.POSS-nephew-DET \\
\hline ka-kíilus-a & & smém'lhats-a & & & \\
\hline
\end{tabular}

'I believe she must have hit my nephew, the girl looks guilty.'

[ $k$ 'a relates to speaker's belief; speaker has inferential evidence]

(63) Context: Lémya7 was babysitting your nephew and niece and she noticed at one point that the boy had a red mark on his face and his sister was looking guilty. She tells you when you get home what she noticed. Then you tell the mother of the kids:

tsuts-Lémya7 kw s-tup-un'-ás $\quad k^{\prime} a \quad$ s-Maria ta

say NOM-Lémya7 DET NOM-punch-DIR-3ERG INFER NOM-Maria DET

$$
\begin{aligned}
& \text { sésq'wez'-s-a } \\
& \text { younger.sibling-3POSS-DET }
\end{aligned}
$$

'Lémya7 said that Maria must have hit her younger brother.'

[k’a relates to Lémya7's belief; Lémya7 has evidence]

Finally, the same is true of -an', as shown in (64-5), where (65) is the semantically embedded reading.

(64) Context: Same as for (62). 


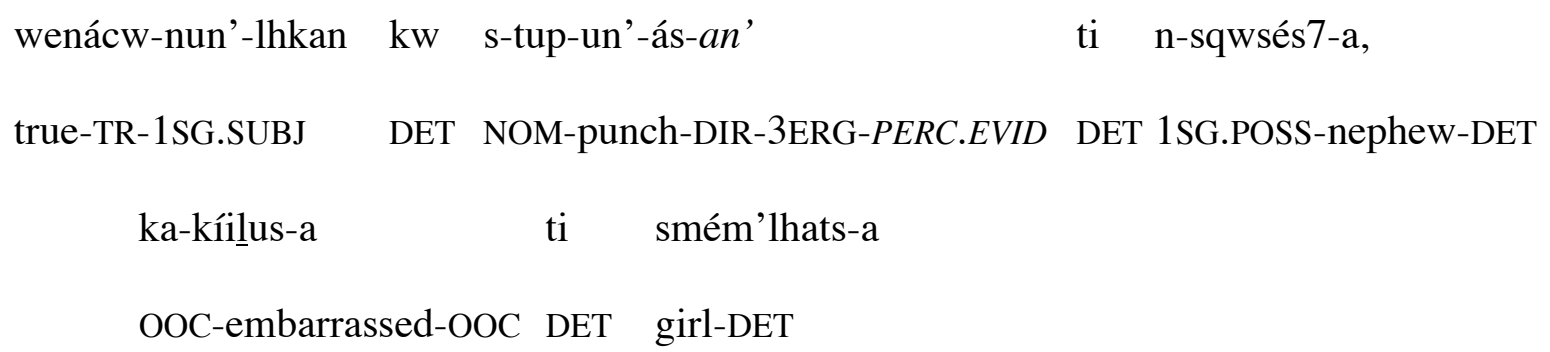

'I believe she must have hit my nephew, the girl looks guilty.'

[-an' relates to speaker's belief; speaker has inferential evidence]

(65) Context: Same as for (63).

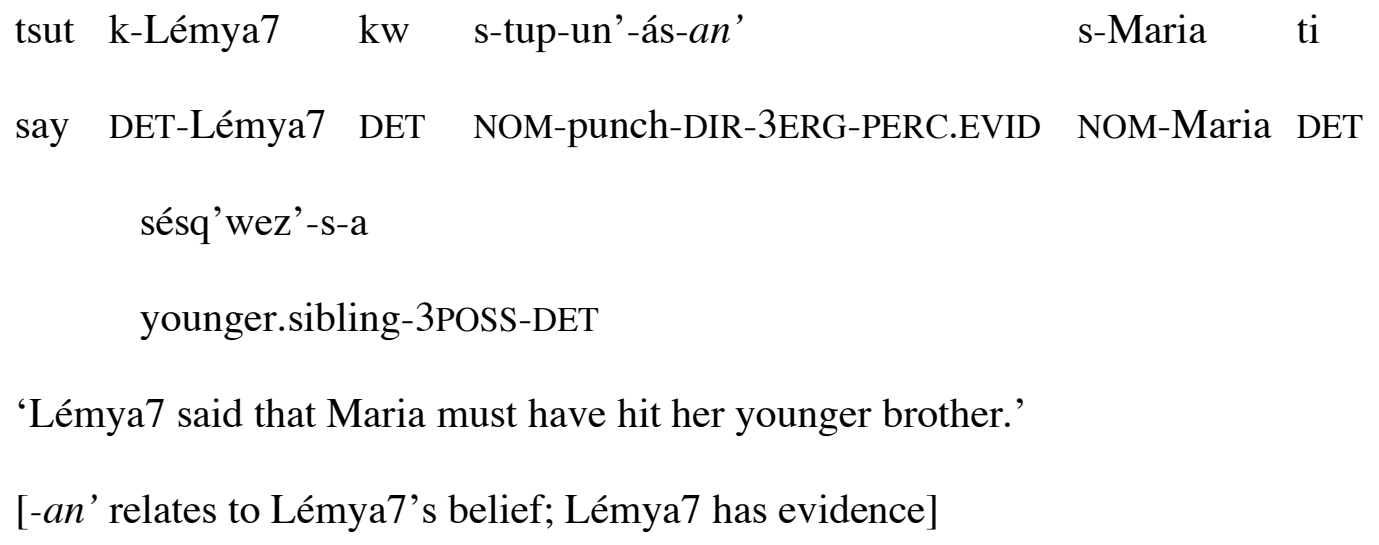

\subsection{Summary}

We have seen that the St'át'imcets evidentials obey the predictions of the modal analysis in every respect. The results are summarized in (66). 


\begin{tabular}{|c|c|c|c|c|}
\hline \multicolumn{2}{|c|}{$(66)$} & $\begin{array}{c}\text { modal } \\
\text { analysis }\end{array}$ & $\begin{array}{l}\text { illoc. op. } \\
\text { analysis }\end{array}$ & $\begin{array}{l}\text { St'át'imcets } \\
\text { evidentials }\end{array}$ \\
\hline 1. & felicitous if $\mathrm{p}$ is known to be false? & no & yes & no \\
\hline 2. & felicitous if $\mathrm{p}$ is known to be true? & no & yes & no \\
\hline 3. & indirect evidence req. cancelable? & no & no & no \\
\hline 4. & indirect evidence req. blocked by negation? & no & no & no \\
\hline 5 . & challengeable? & yes & no & yes \\
\hline 6. & embeddable? & yes & no & yes \\
\hline
\end{tabular}

We conclude that the St'át'imcets evidentials are epistemic modals.

\section{The St'át'imcets evidentials do not encode distinctions of speaker certainty}

According to de Haan (1999), evidentials are distinguishable from epistemic modals: the former encode the source of information, while the latter encode the speaker's certainty level about the proposition expressed. For example, de Haan argues that Dutch moeten is ambiguous between an epistemic modal and an evidential. ${ }^{26} \mathrm{He}$ argues that under its epistemic reading, moeten 'denotes a high degree of confidence in the truth of the statement on the part of the speaker'. He explicitly compares epistemic moeten to English epistemic must. However, on its evidential interpretation, moeten allows continuations that express either confidence or doubt. The evidential uses are illustrated in (67).

26 Moeten also allows a deontic modal interpretation, which is not relevant here. 
a. het moet een goede film zijn, en ik ben daar zeker van it must a good movie be and I am there sure of 'It is said to be a good film, and I am convinced of it.' (de Haan 1997:16)

b. het moet een goede film zijn,maar ik heb er mijn twijfels over it must a good movie be but I have there my doubts about 'It is said to be a good movie, but I have my doubts about that.' (de Haan 1997:17)

Within the possible worlds semantics for modals, variation in certainty levels equates with variation in the strength of the quantification over possible worlds. Thus, a speaker who uses an existential modal is less certain about the truth of the embedded proposition than a speaker who uses a universal modal: the speaker of (68b) is less certain about the truth of (68a) than the speaker of $(68 \mathrm{c})$ is.

(68) a. Michl is the murderer.

b. Michl might be the murderer.

c. Michl must be the murderer.

In Rullmann, Matthewson and Davis (2006), we show that a wide range of modals in St'át'imcets display variability in quantificational force. In particular, we show that (just like de Haan claims for Dutch epistemic moeten), the St'át'imcets evidential clitics do not lexically specify the level of the speaker's certainty. This is in spite of the evidence given in the preceding section that the St'át'imcets evidential clitics must be analysed as epistemic modals. Here we will present 
some of the data for inferential $k^{\prime} a$, referring the reader to our earlier work for further data and argumentation.

The examples in (69-71) are all drawn from spontaneously-produced oral narratives. (69) is an example of a universal epistemic claim. Immediately following (69) in the story, the speaker explains that a neighbour got angry at her and her friends. The speaker clearly perceives the anger to be a result of the loudness.

(69) Context: Speaker is telling about when she was a child and she used to play in the evenings with her friends.

$\begin{array}{llll}\text { na s-pála7-s-a, } & \text { wá7-lhkalh } & k^{\prime} a & \text { wenácw-ts-am' } \\ \text { DET NOM-one-3POSS-DET } & \text { IMPF-1PL.SUBJ } & \text { INFER } & \text { true-mouth-MID }\end{array}$

'One time, we must have been loud.'

(Matthewson 2005:410)

In (70), there is strong evidence in the context that Jim Hoffmann is frightened. The context thus involves a high degree of certainty on the part of the speaker and therefore supports a universal epistemic modal claim.

(70) Context: Jim Hoffmann thought he saw a sasquatch and came running back with huge terrified eyes.
ka qus-tum'-á
k’a wi7
OOC frighten-PASS-OOC INFER EMPH

'It really must have frightened him!'

(Matthewson 2005:418) 
(71) is taken from a text and appears to involve existential force. The first sentence explicitly states that the speaker is unsure about the truth of the proposition embedded under $k^{\prime} a$ in the second sentence. Note that we cannot conclude in this context that the speaker's mother must have put the fish away for eating later. She could have given it to relatives instead.

$\begin{array}{llrlrl}\text { cw7aoz } & \text { kw-en-wá } & \text { stexw } & \text { lexláx-s } & \text { lh-as } \\ \text { NEG } & \text { DET-1SG.POSS-IMPF } & \text { very } & \text { remember-CAUS } & \text { HYP-3CONJ } \\ \text { kás-tum' } \quad \text { i } \quad \text { sk'wílh-a } & \text { ts'úqwaz' } & \\ \text { what-1PL.ERG DET.PL leftover-DET } & \text { fish } & \\ \text { 'I don't remember what we did with the leftover fish.' }\end{array}$

wa7 k'a qelh-n-ás nilh kw s-ts’áqw-an'-em lh-kalál-as IMPF INFER put.away-DIR-3ERG FOC DET NOM-eat-DIR-1PL.ERG HYP-soon-3CONJ 'Maybe she put it away and we ate it later.' (Matthewson 2005:58)

An elicited example involving existential force is given in (72). Here, a continuation asserting that perhaps the embedded proposition is false is accepted by consultants.

(72) Context: There is some evidence that John has left, e.g. his bag has gone, but maybe he just took his bag to the bathroom.

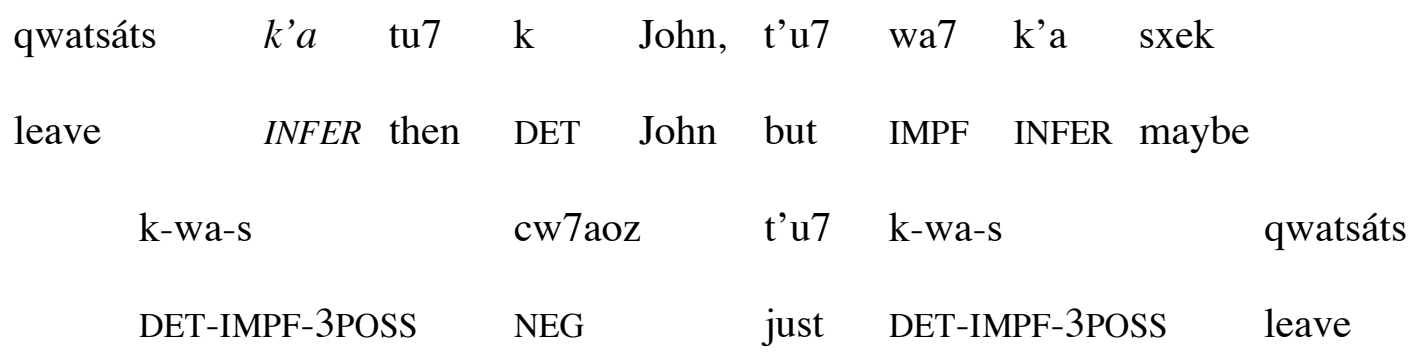


'John may (\#must) have left, but maybe he hasn't left.'

A final (volunteered) example which forces existential quantification is given in (73).

(73) Context: There is some evidence that John has left, e.g. his bag has gone, but maybe he just took his bag to the bathroom.

qwatsáts $k^{\prime} a \quad$ tu7 $\quad \mathrm{k} \quad$ John, t'u7 sxek $\quad$ cw7aoz $k^{\prime} a \quad$ kw $\quad$ s-qwatsáts leave INFER then DET John but maybe NEG INFER DET NOM-leave 'John may have left, but he may not have left.'

In summary, we see that $k^{\prime} a$ is lexically restricted to involving indirect inferential evidence and thus lexically specifies the source of the information - but is apparently not lexically restricted in terms of its quantificational force / certainty level. The perceived-evidence clitic -an' and the reportative $k u 7$ also allow both universal and existential interpretations, although the universal is strongly preferred. See Rullmann, Matthewson and Davis (2006) for discussion of this point.

\section{A modal analysis of St'át'imcets evidentials}

In this section we present our formal analysis of the St'át'imcets evidentials. The reader is referred to Rullmann, Matthewson and Davis (2006) for further explanation. The basic idea is inspired by Klinedinst's (2005) work on possibility modals in English. Klinedinst argues that possibility modals are analogous to plural indefinite DPs. In the same way that plural indefinites existentially quantify over pluralities of entities, possibility modals existentially quantify over pluralities of possible worlds. The individual worlds that are members of the plurality of worlds introduced by the 
existential quantifier are then universally quantified over. The logical structure of possibility modals can be represented as in (74):

$$
[[\operatorname{MODAL}(\mathrm{B})(\mathrm{w})(\phi)]]=1 \text { iff } \exists \mathrm{W}[\mathrm{W} \subseteq \mathrm{B}(\mathrm{w}) \wedge \forall \mathrm{w}[\mathrm{w} \in \mathrm{W} \rightarrow \varphi(\mathrm{w})]]
$$

(adapted from Klinedinst 2005:19)

The modal is interpreted with respect to a given modal base B and a possible world w (the evaluation world). $\mathrm{B}(\mathrm{w})$ is the set of worlds that are accessible from the evaluation world w given the modal base B. The right-hand side of (74) can therefore be paraphrased as "there is a set of worlds $\mathrm{W}$ that are accessible from $\mathrm{w}$, such that $\varphi$ is true in every world in W", or more succinctly, "in some set of accessible worlds $\mathrm{W}, \varphi$ is true".

We adopt Klinedinst's proposal as the basis for an analysis of all modals in St'át'imcets, but with a twist. Within Klinedinst's analysis, assuming W is non-empty, (74) is truth-conditionally equivalent to the traditional existential interpretation of possibility modals. We propose that St'át'imcets modals are analogous to specific plural indefinites ("there is a specific set of worlds W...”). We adopt a particular formal interpretation of specific indefinites involving choice functions (Reinhart 1997, Winter 1997, Kratzer 1998, Matthewson 1999, among others). In the same way that a choice function representing a specific indefinite determiner picks out an individual from the set denoted by the common noun (or NP), the modal choice function $\mathrm{f}$ will pick out a subset of the possible worlds that are accessible from the actual world. The universal quantifier then quantifies over the individual worlds that are members of the set picked out by $\mathrm{f}$. Thus the interpretation of St'át'imcets modals can be represented as in (75).

$$
[[\operatorname{MODAL}(\mathrm{f})(\mathrm{B})(\mathrm{w})(\phi)]]=1 \text { iff } \forall \mathrm{w}^{\prime} \in \mathrm{f}(\mathrm{B}(\mathrm{w})):\left[\left[\phi\left(\mathrm{w}^{\prime}\right)\right]\right]=1
$$


According to our analysis, St'át'imcets modals thus involve two contextually determined parameters, the modal base B and the choice function $\mathrm{f}$. The modal base $\mathrm{B}$ functions in the same way as it does in Kratzer's analysis of English modals: it is a function which maps the evaluation world $\mathrm{w}$ onto the set of possible worlds that are accessible from it. The choice function $\mathrm{f}$ picks out a subset of $\mathrm{B}(\mathrm{w})$. The semantic type of $\mathrm{f}$ is therefore $<s t, s t>$. $\mathrm{f}$ is moreover restricted in such a way that, for any set of worlds W, $\mathrm{f}(\mathrm{W}) \subseteq \mathrm{W}$. Following Kratzer's (1998) analysis of specific indefinites, we propose that $\mathrm{f}$ is a free variable whose value is determined by context.

How then does our analysis account for the apparent variability of the quantificational force of modals in St'át'imcets? We locate this in the choice of $\mathrm{f}$ rather than in the quantifier, which is uniformly universal. The larger the subset of $\mathrm{B}(\mathrm{w})$ that is selected by $\mathrm{f}$, the stronger the proposition that is expressed. As a limiting case, f may simply be the identity function. This results in a reading that is fully equivalent to the standard analysis of strong modals like must in English. However, if $\mathrm{f}$ selects a proper subset of $\mathrm{B}(\mathrm{w})$, the resulting reading is weaker, although it still involves universal quantification.

According to this proposal, the apparent quantificational variability of modals in St'át'imcets is not due to ambiguity or underspecification of the modal quantifier itself, because it is uniformly universal. It also does not involve a dichotomy between two readings (one strong and one weak). Rather, there is a continuity of different degrees of strengths, depending on the size of the subset of $B(w)$ that is selected by $f$. The smaller $f(B(w))$ is, the more restricted the universal quantifier is, and the more likely it is to be translated as English may, could, or might rather than must. However, this apparent ambiguity is only an artifact of using English as the translation medium.

The analysis of the individual evidentials is given in (76-8). 
$\left[\left[k^{\prime} a(f)(B)(w)(\phi)\right]\right]$ is only defined if for all worlds w', w' $\in \mathrm{B}(\mathrm{w})$ iff the inferential evidence in w holds in w', and $\mathrm{f}$ is a choice function of type <st,st $>$ such that $\mathrm{f}(\mathrm{B}(\mathrm{w})) \subseteq \mathrm{B}(\mathrm{w})$. If defined, $\left[\left[k^{\prime} a(\mathrm{f})(\mathrm{B})(\mathrm{w})(\phi)\right]\right]=1$ iff for $\forall \mathrm{w}^{\prime} \in \mathrm{f}(\mathrm{B}(\mathrm{w})):\left[\left[\phi\left(\mathrm{w}^{\prime}\right)\right]\right]=1$.

(77) Semantics of -an' (perceived-evidence) $\left[\left[-a n^{\prime}(f)(B)(w)(\phi)\right]\right]$ is only defined if for all worlds $w^{\prime}, w^{\prime} \in B(w)$ iff the perceived evidence in w holds in w', and $\mathrm{f}$ is a choice function of type <st,st> such that $\mathrm{f}(\mathrm{B}(\mathrm{w})) \subseteq$ $B(w)$.

If defined, $\left[\left[-a n^{\prime}(\mathrm{f})(\mathrm{B})(\mathrm{w})(\phi)\right]\right]=1$ iff for $\forall \mathrm{w}^{\prime} \in \mathrm{f}(\mathrm{B}(\mathrm{w})):\left[\left[\phi\left(\mathrm{w}^{\prime}\right)\right]\right]=1$.

\section{(78) Semantics of $k u 7$ (reportative)}

$[[k u 7(\mathrm{f})(\mathrm{B})(\mathrm{w})(\phi)]]$ is only defined if for all worlds $\mathrm{w}^{\prime}, \mathrm{w}^{\prime} \in \mathrm{B}(\mathrm{w})$ iff the reported evidence in $\mathrm{w}$ holds in $\mathrm{w}^{\prime}$, and $\mathrm{f}$ is a choice function of type $<$ st,st $>$ such that $\mathrm{f}(\mathrm{B}(\mathrm{w})) \subseteq \mathrm{B}(\mathrm{w})$. If defined, $[[k u 7(\mathrm{f})(\mathrm{B})(\mathrm{w})(\phi)]]=1$ iff for $\forall \mathrm{w}^{\prime} \in \mathrm{f}(\mathrm{B}(\mathrm{w})):\left[\left[\phi\left(\mathrm{w}^{\prime}\right)\right]\right]=1$.

\section{$7 \quad$ St'át'imcets evidentials and the syntax-semantics mapping}

So far, we have said little about the syntactic status of evidentials in St'át'imcets, aside from the fact that they are second position clitics. In this section, we examine their morphosyntactic behaviour in more detail, in the light of current debates about the crosslinguistic status of evidential markers, and the relationship between their semantics and their morphosyntax. In particular, we will be concerned with the following questions:

1. Do St'át'imcets evidentials form a morphological paradigm? 
2. Do St'át'imcets evidentials occupy fixed positions in a syntactic hierarchy of functional projections?

The first question is relevant in view of Aikhenvald's (2004) claim that languages fall into two sets with respect to their treatment of evidentiality. Members of the first set have 'grammaticalized' evidentiality, so that it forms (like tense and agreement in English) an obligatory, paradigmatically organized system. Members of the second set express evidentiality through optional and morphosyntactically heterogeneous means, including adverbs, higher predicates, and spatio-temporal demonstratives. We will show that St'át'imcets certainly falls into the second class: even though it marks evidential notions more frequently and more consistently than languages such as English, its evidential markers are optional, do not form an inflectional paradigm, and are morphosyntactically heterogeneous.

The second question relates to the 'cartographic' approach to evidentiality pioneered by Cinque (1999) and extended by Speas (2004), in which evidential markers occupy a fixed, universal position in a hierarchy of functional projections which also includes speech act markers, expressions of modality, and other clause-level operators. Since such a view is at least partly dependent on the underlying assumption that particular evidentials (e.g., inferentials, reportatives) have a uniform semantics, and since we reject this assumption (see section 3 above), we are also led to reject a uniform, hierarchically rigid view of evidential syntax. We will see that at least for St'át'imcets, there is little to recommend this view from a syntactic perspective, either. Nevertheless, to the extent that the morpheme order and scope possibilities of evidentials are consistent with each other, both within a particular language and across languages, we are sympathetic to a looser association between evidential semantics and syntax, as proposed by Blain and Déchaine (in press) in terms of evidential 'domains' in the syntactic representation. 
In the following subsections we will elaborate on these proposals: 7.1 deals with the morphological organization of evidentials and 7.2 with their syntactic representation.

\subsection{Do St'át'imcets evidentials form a 'grammatical system'?}

Aikhenvald (2004:11) claims that about a quarter of the world's languages encode evidentiality (source of knowledge) as part of the grammar, where 'grammar is taken to deal with closed systems, which can be realized through bound morphemes, clitics, and words which belong to full grammatical word classes, such as prepositions, preverbs, or particles.' Other languages (possibly all other languages) may encode information source either lexically (in the form of adverbs, for example) or as secondary "extensions" of grammatical categories such as tense, mood, or aspect, but for Aikhenvald, these do not form evidential systems: 'Evidentiality only marginally relates to truth value, reliability of information, speaker's responsibility, and epistemic meanings (related to possibility and probability)' (Aikhenvald 2004: 364).

Clearly, we are in disagreement with the contention that evidentiality only marginally relates to truth value or epistemic modality, since we analyse evidential markers in St'át'imcets as (a special kind of) epistemic modals. However, we have not addressed the issue of whether St'át'imcets evidentials form a grammatical system in Aikhenvald's sense: that is, a system of semantic oppositions obligatorily encoded by a paradigmatically organized set of closed class elements. In fact, it turns out that in spite of the clearly evidential meanings of $k u 7, k^{\prime} a$ and -an', these clitics do not form part of an 'evidential system' in this sense.

We will present four arguments for this conclusion. First, there appears to be no direct evidential in the language - not even a null one. There is thus a 'missing cell' in the evidential paradigm - in fact, the unmarked cell. Second, evidential use is never obligatory in St'át'imcets: in general, evidentials are used where they are informative, unlike, say tense marking in English, 
which must be used whether redundant or not. Third, at least some members of the St'át'imcets evidential 'paradigm' may co-occur. And finally, evidentials do not form a homogeneous morphosyntactic class in St'át'imcets: though the three elements we have examined in detail are all second position clitics, this class is itself heterogeneous, comprising, besides evidentials, speech act operators, modals, tense markers, and even demonstrative pronouns. Moreover, there is a fourth marker - the demonstrative adverb lákw7a - whose meaning is clearly evidential, but whose morphosyntax is completely distinct from that of the second position clitics.

Let us turn to the first argument: the absence of a direct evidential. Some clarification is in order here, since it is sometimes asserted about Salish languages that sentences without any markers of evidentiality do involve direct speaker witness. For example, Davis and Saunders (1975:15) state that 'any declarative utterance in Bella Coola implies that the speaker has witnessed what he reports; a 'declarative utterance' is one which does not contain any of a set of speaker-knowledge particles. Similarly, Matthewson (1998:160) argues for St'át'imcets that 'a declarative sentence without any speaker-knowledge particles unambiguously implies that the speaker has personal knowledge of the events or states reported on.' Matthewson cites the following data:

(79) a. zac-al'qwem' k John long-appear DET John 'John is tall.' (Speaker has seen John, and knows first-hand that John is tall.)

b. túp-un'-as s-John ti plísmen-a punch-DIR-3ERG NOM-John DET policeman-DET

'John hit a policeman.' (Speaker witnessed the event.) ～(Matthewson 1998:160) 
Matthewson concludes that 'the non-ambiguity of a sentence which contains no particles suggests that in such sentences there is a null particle with a default interpretation of 'speaker witness'.'

However, subsequent investigation has revealed that the tendency for sentences without overt evidentials to involve speaker witness is only an implicature. This implicature naturally arises due to the presence in the language of overt clitics which encode indirect evidentiality of various types. If the speaker chooses not to use overt means of indicating indirect evidence, then the hearer infers that the evidence was obtained via direct speaker witness.

The evidence that the speaker witness effect is only an implicature is as follows. In languages with a real direct evidential, contradictions obtain when one combines the direct evidential with a claim that the evidence was not obtained directly. For example, Pancheva (2005) shows that in Bulgarian, the direct evidential is incompatible with verbs of saying. Thus, one cannot say 'Ivan said that he drank the wine yesterday' using a direct evidential in the embedded clause. Pancheva notes that the status of such sentences improves if 'said' is interpreted as 'acknowledged' - that is, in a context where the speaker did see Ivan drink the wine, and the sentence reports that Ivan later acknowledged having done so.

Similarly, in Korean, the indirect evidential -ess contrasts strictly with direct evidential cases. Chung (2005, in press) shows that in the absence of any other tense or aspect forms, the suffixes -ney or -te result in a direct evidential meaning, whereby the speaker witnessed the event. This is illustrated in (80).
a. mina-ka
chayk-ul ilk-ney
Mina-NOM
book-ACC
read-S.PRES
'[I see] Mina is reading a book.' 
b. mina-ka chayk-ul ilk-te-la

Mina-NOM book-ACC read-S.PAST-DEC

'[I saw] Mina was reading a book.' ， (Chung in press:3-4)

Although Chung shows that the suffix -te, for example, does not always indicate speaker witness (that is, the system is more complicated than this over-brief summary implies), there are in at least some cases strong effects, such that the sentence is unacceptable if it is impossible for the speaker to have witnessed the event. This is illustrated in (81).

$(81) * \mathrm{ku}$ tansi shakespeare-ka ce cip-ey sal-te-la that time Shakespeake-NOM that house-LOC live-TE-DECL '[I saw] Shakespeare was living in that house at that time.' $\quad$ (Chung 2005:120)

Neither of these test constructions give rise to the same result in St'át'imcets; evidential-less clauses are entirely acceptable in the complement of a verb of saying, as shown in (82-3), and the absence of speaker witness does not cause a declarative sentence be judged as ungrammatical. (83) shows that even folklore can be expressed without any overt evidential.

\begin{tabular}{|c|c|c|c|}
\hline (82) & wa7 & tsút-wit & k-wa-s \\
\hline & IMPF & say-3PL & DET-IMPF-3POSS \\
\hline
\end{tabular}

'They said it was white.'

(Matthewson 2005:227)

Context: The speaker is talking about a car that hit her son's car. She did not personally witness the white car. 


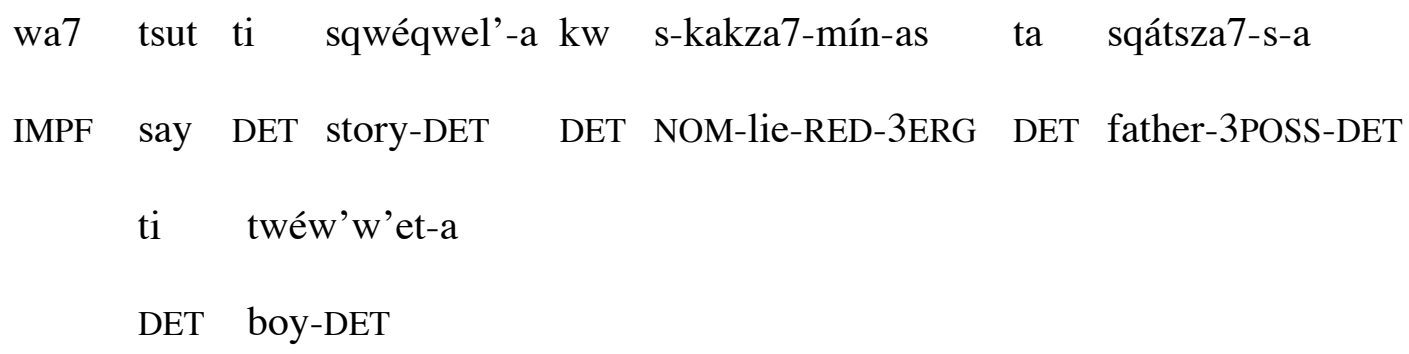

'The story says that this boy lied about his father.'

(Matthewson 2005:106)

(84) is directly parallel to the Bulgarian example 'Ivan said that he drank the wine'. In Bulgarian, this is bad with a direct evidential in the embedded clause. (85) is directly parallel to the Korean example from Chung above concerning Shakespeare. The speaker of (85) cannot have witnessed Shakespeare living in the house, yet the plain form is fine.

tsut k Dale kw $\quad$ s-ts'áqw-an'-as i ts'wán-a $\quad$ i-nátcw-as say DET Dale DET NOM-eat-DIR-3ERG DET wind-dried salmon when.PAST-day-3CONJ 'Dale said he ate the ts'wan yesterday.'

wa7 tu7 wá7 1-ta tsítcw-a láti $\mathrm{kw}$ Shakespeare IMPF then be in-DET house-DET DEIC DET Shakespeare 'Shakespeare lived in that house.'

The absence of a direct evidential in St'át'imcets is compatible with our claim that the three evidential clitics are epistemic modals, rather than part of an evidential paradigm which must also encode direct evidentiality. ${ }^{27}$

\footnotetext{
${ }^{27}$ It is interesting in this respect that while Quechua possesses a direct evidential (-mi), in line with
} 
Our second argument against the existence of an evidential paradigm is linked to the first. Since as we have just seen, there are sentences which lack any evidential specification (those where the source of evidence must be construed as indirect, even when there is no evidential marker), it follows that evidential marking cannot be obligatory in St'át'imcets, unlike for example tense marking in Germanic or Romance languages, or mood in Wakashan languages. It is particularly easy to see this in traditional stories, where the reportative enclitic $k u 7$ is certainly appropriate (since the speaker by definition has not witnessed the events $\mathrm{s} / \mathrm{he}$ describes), and is in fact frequently used - but as a stylistic device, rather than an obligatory grammatical category. For example, in the earliest recorded narrative of any length in St'át'imcets, the myth of Kayám (HillTout 1905, retranscribed in Davis 2001), there are just ten instances of reportative $k u 7$ in 158 lines of text. Moreover, the first use of $k u 7$ is in line 28, well after the major narrative threads have been introduced into the story. This argues against any attempt to explain the absence of $k u 7$ in appropriate environments as being anaphoric to a previously introduced instance of the same morpheme - there simply is no overt antecedent $k u 7$ to license a null anaphor. We conclude that evidentials in St'át'imcets are - and have always been - optional rather than obligatory in appropriate contexts, contrary to the predictions of an analysis which treats them as members of a grammatical paradigm.

what we would expect were evidentials to be paradigmatically organized, it also allows sentences without any evidential. A Quechua sentence without an evidential implicates a direct evidential meaning, just as in St'át'imcets, as opposed to a sentence containing -mi, which encodes the direct evidentiality in the sincerity condition. This suggests that even in Quechua - often taken to be an archetypical case of a grammaticalized evidential system - evidentiality is not obligatorily expressed, and therefore does not have the status of an inflectional paradigm. 
Our third argument against treating evidentials as part of a single paradigm in St'át'imcets is quite simple: evidential markers may co-occur. The following examples, involving $k u 7$ and $k^{\prime} a$, are taken from van Eijk (1997:209):

\begin{tabular}{|c|c|c|c|c|c|}
\hline ..lans & $k u 7$ & $k^{\prime} a$ & n-ts'aqw-q-án'-em & é-ki & scúcwez'-c \\
\hline already & REPORT & INFER & LOC-eat-bum-DIR-PASS & by-DET.COLL & ant-DET \\
\hline
\end{tabular}

qwatsats $k u 7 \quad k$ 'á tu7 i wa7 es-tsmál't
leave REPORT INFER then DET.PL IMPF
"The parents had left apparently, as I am told." 28

This co-occurrence pattern provides straightforward counter-evidence against a paradigmatically organized evidential 'system'.

Our final argument is that evidentials in St'át'imcets do not show uniform morphosyntactic behaviour. This point is somewhat obscured by the fact that the three evidentials which have been the focus of this paper all have the surface status of second position clitics. But in fact, the fifteen or so elements which make up the 'clitic string' in St'át'imcets are grammatically diverse - they include speech act markers, modals, various discourse particles, tense markers, and even 'weak' demonstrative pronouns. (The latter in particular are clearly prosodically rather than syntactically positioned, since when stressed, they occupy standard argument positions: see van Eijk 1997:169).

\footnotetext{
28 Not all our consultants accept sentences like (88) and (89): however, both Davis (in prep.) and van Eijk (1997) have recorded them.
} 
In other words, second position status tells us little in itself about the grammatical relatedness or otherwise of the evidential markers. (We will return to the issue of clitic ordering below.) In fact, in spite of their common status as clitics, $-a n^{\prime}, k u 7$ and $k^{\prime} a$ show differences in morphological and syntactic behaviour. As pointed out in footnote 4 above, - $a n^{\prime}$ is distinctive in several ways. First, it obligatorily induces conjunctive (subjunctive) subject morphology, unlike any other clitic in the language. This cannot be for semantic reasons, since the inferential clitic $k^{\prime} a$, whose meaning - as we have shown - encompasses that of -an', does not obligatorily induce conjunctive marking. Second, -an', unlike any other second position element, shows properties both of clitics and of suffixes. Its shape is that of a suffix (since vowel-initial clitics are not permitted), ${ }^{29}$ and it occurs inside (preceding) the suffixal portion of the out-of-control circumfix $k a-\ldots-a$, as shown in (88).

ka-guy't-as-án'-a tu7

OOC-sleep-3CNJ-PERC.EVID-OOC then

'It looks like he's fallen asleep.' ～(Davis in prep.)

However, unlike any other suffix, but like other second position clitics, -an' attaches to the first of a sequence of pre-predicative auxiliaries, leading to an ordering paradox, as can be seen by comparing (88) with (89):

29 With the exception of the element $-a$, which is also exceptional: it has no independent meaning of its own, but instead is used to 'reinforce' a disparate collection of other elements, including existence-asserting proclitic determiners in DP, the second position clitics cwilh and qa7, and prosodically 'unbalanced' clitic strings with an unparsed final foot. 


$$
\begin{array}{lll}
\text { plan-as-án' } & \text { tu7 } & \text { ka-gúy't- } a \\
\text { already-3CONJ-PERC.EVID then } & \text { OOC-sleep-OOC }
\end{array}
$$

'It looks like he's already fallen asleep.'

(Davis in prep.)

In contrast to - $a n^{\prime}, k u 7$ and $k^{\prime} a$ are well-behaved second position clitics. However, they differ in their distribution outside of the clitic string: whereas $k u 7$ never appears except as an enclitic, $k^{\prime} a$ is quite frequently employed as a main predicate taking a $\mathrm{CP}$ complement (like many other sentencelevel adverbs). In its main predicate guise, $k$ ' $a$ is usually translated as 'maybe', and is often employed in a construction of the form 'maybe $X$, maybe $Y$ ', which yields the St'át'imcets equivalent of clausal disjunction:

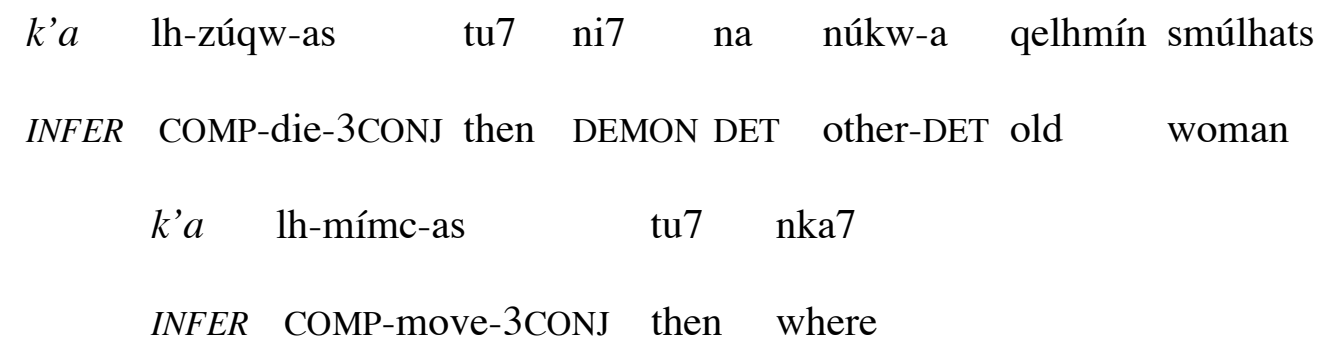

'Maybe the other old woman died or maybe she moved somewhere.' (Matthewson 2005:61)

In summary, of the three evidential enclitics, only $k u 7$ is unambiguously clitic-like in its behaviour: -an' shows characteristics of both a suffix and a clitic, and k'a alternates between main predicate and clitic uses. This heterogeneous behaviour once again argues against assimilating evidential elements to a single paradigm.

An even stronger argument for the morphosyntactic heterogeneity of evidential elements in St'át'imcets comes from a fourth element, which we have discussed so far only in passing. This is the demonstrative adverb lákw7a, which has the meaning 'perceived by other than visual modality'; 
we gloss it here as non-visual. Its semantics clearly places it as a core marker of evidentiality, as can be seen in the following examples:

(91) áma lákw7a!

good NON-VISUAL

'That tastes good!'

(Common expression used when speaker can taste but not see something - typically, when it's in their mouth.)

(Davis in prep.)

(92) wa7 lákw7a ku ts7ás-a

IMPF NON-VISUAL DET COMe- DET

'Someone's coming.' (The speaker can hear them, but not see them.) (Davis in prep.)

(93) huz’ lákw7a kwis

going.to NON-VISUAL rain

'It feels like rain.'

(van Eijk 1997:173)

(94)

saq'úta-lhkacw lákw7a

dance-2SG.SUBJ $\quad$ NON-VISUAL

'I heard you danced.' (St'át'imcets volunteered)

(Note that in this last example the meaning of lákw7a overlaps with that of reportative $k u 7$. )

While it is semantically an evidential, the syntax of lákw7a is quite distinct from that of any of the other three evidential elements discussed here, and similar to others of its morphosyntactic 
class, which comprises locative and temporal demonstrative adverbials. These elements are never clitics, since they are inherently stressed. They are positioned fairly freely in post-predicative positions, with a mild preference for second position, as in the examples above; unlike clitics, they may also be focused (see van Eijk 1997:173 for examples). In other words, lákw7a is semantically an evidential, but syntactically a demonstrative adverb, providing a final strong argument against treating evidentials in St'át'imcets as part of a grammatical paradigm.

These arguments are particularly important in that a superficial typological survey, based on the standard descriptive grammar of the language (van Eijk 1997) would probably come to the opposite conclusion - that is, that the three evidential enclitics in St'át'ímcets, along with a zeromarked direct evidential comprise a grammaticalized, four term evidential system. ${ }^{30}$ Moreover, it suggests that only a relatively detailed examination of the morphosyntax as well as the semantics of evidential markers in a given language is likely to yield reliable information on the putative existence of a grammaticalized evidential system. Of particular importance in this respect is the (non-)existence of a zero-marked direct evidential; this appears to us to be the key characteristic of a paradigmatically organized system, as opposed to the 'scattered coding of evidentiality' described by Aikhenvald (2004:80).

\subsection{Are evidentials in St'át'imcets organized in a functional hierarchy?}

We now turn to the issue of whether the morphosyntactic properties of evidentials are amenable to an analysis along the lines of Cinque (1999) and Speas (2004) (see also Rooryck 2001a,b for a

30 We should point out that in her brief discussion of evidentiality in Salish, Aikhenvald (2004:59) is appropriately circumspect, due to the lack of detailed evidence available in the published material on Salish languages (including St'át'imcets). 
Cinque-style analysis of some evidentials). The basic claim of these authors is that evidentials are syntactic heads, organized in a rigid hierarchy of functional projections above the VP. Note that, unlike the claim that evidentials form a grammatical system distinct from that of modals, this 'cartographic' approach to morphosyntactic representation is at least in principle compatible with our own proposal that evidentials are a subspecies of modal - as long as they occupy a unique set of positions in the functional hierarchy. In fact, Cinque labels 'evidential' as a subtype of 'Mood', as can be seen in (95), from Cinque 1999:76): 31

$$
\begin{aligned}
& \operatorname{Mood}_{\text {speech act }}>\operatorname{Mood}_{\text {evaluative }}>\operatorname{Mood}_{\text {evidential }}>\operatorname{Mod}_{\text {epistemic }}>\mathrm{T}(\text { Past })>\mathrm{T}(\text { Future })>\operatorname{Mood}_{\text {irrealis }}> \\
& \operatorname{Asp}_{\text {habitual }}>\mathrm{T}(\text { Anterior })>\operatorname{Asp}_{\text {perfect }}>\operatorname{Asp}_{\text {retrospective }}>\operatorname{Asp}_{\text {durative }}>\operatorname{Asp}_{\text {progressive }}>\operatorname{Asp}_{\text {prospective }} \\
& / \operatorname{Mod}_{\text {root }}>\operatorname{Asp}_{\text {prospective }}>\text { Voice }>\operatorname{Asp}_{\text {celerative }}>\operatorname{Asp}_{\text {completive }}>\operatorname{Asp}_{(\text {semel)repetitive }}>\operatorname{Asp}_{\text {iterative }}
\end{aligned}
$$

It is unclear, however, from Cinque's relatively brief discussion of evidentiality whether he wishes to include all evidentials under the 'Evidential Mood' head. This is partly a question of definition: for example, under our analysis, evidentials are epistemic modals, so some or all of them could presumably be generated under the Epistemological Modality head in addition to or instead of the Evidential Mood head. Cinque himself sometimes seems unsure of the distinction: the examples he gives of evidential mood are mostly reportative morphemes (from Korean, Hidatsa, Kewa, Turkish,

\footnotetext{
31 Cinque's use of 'mood' is non-standard; normally mood is taken to represent a paradigmatically organized inflectional category containing a cross-linguistically variable amalgam of syntactic and semantic features. See Mithun (1999) for a discussion of mood in Amerindian languages, and from a different perspective - Portner's (1997) formal analysis of mood in the framework of possible world semantics.
} 
Ute, Quechua, and Basque), but he treats the Korean 'conjectural' morpheme (surely an evidential) as a manifestation of epistemic modality instead. The reason for this is probably that the reportative (-ti) and conjectural (-keyss) morphemes co-occur in Korean, as shown by one of Cinque's own examples, given here:

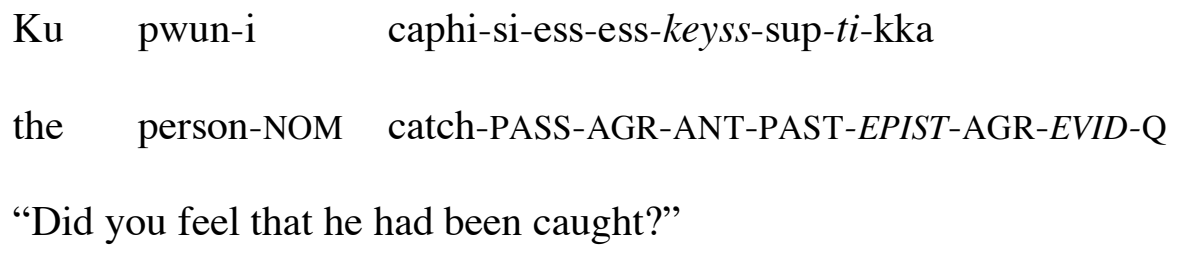

(Cinque 1999:53)

As long as it is assumed that there is a single locus of evidential marking, the co-occurrence of two evidentials is problematic: hence Cinque's decision to treat the inner one as a marker of epistemic modality. However, we have already seen on the basis of data from St'át'imcets that this assumption is false: evidentials need not necessarily occupy a unique morphological slot, and are not necessarily in complementary distribution.

Speas (2004) does consider a more distributed view of the mapping of evidential semantics onto functional heads, in which each of the top four projections in Cinque's hierarchy has a corresponding evidential type, as follows:

$\begin{array}{ll}\text { Cinque's projection } & \text { Evidential type } \\ \text { Speech Act Mood } & \text { 'hearsay' } \\ \text { Evaluative Mood } & \text { 'indirect evidence' } \\ \text { Evidential Mood } & \text { 'direct evidence' } \\ \text { Epistemic Modality } & \text { 'experiential' }\end{array}$


Such an approach is more compatible with our own (and, we feel, with the cross-linguistic evidence on evidential morphosyntax), though we do not necessarily agree with the precise details of the correspondences proposed in (97). Unfortunately, however, Speas goes on to reject this whole approach, since it clashes with the assumption that evidentials must occupy a single slot in the functional hierarchy:

Looking first at the typology of evidential morphemes, our first impulse might be to say that the four head positions of Cinque correspond to the four types of evidential morphemes. However, in some languages evidential morphemes co-occur with morphemes marking Speech Act Mood, Evaluative Mood and/or Epistemological Mode. Furthermore, we do not find languages that allow sequences of evidential morphemes. Thus, it seems clear that evidential morphemes occupy just the head of Evidential Phrase (Speas 2004:22). ${ }^{32}$

However, we $d o$ find languages that allow sequences of evidential morphemes (for example, St'át'imcets and Korean, as pointed out above). It follows that Speas's conclusion cannot be correct.

Accordingly, let us provisionally adopt a view of the functional hierarchy in which

32 Speas (2006) revises her earlier proposals concerning the representation of evidentiality in the syntactic representation. In particular, she treats evidentials as agreement morphemes encoding a hierarchy of features parallel to that suggested for pronouns by Harley and Ritter (2002). As agreement morphemes, evidentials are co-indexed with a world variable parallel to the individual variable of personal pronouns. Though distinct from her earlier proposals, this approach adopts the same assumptions regarding the position of evidential heads in the functional super-structure: that is, that evidentiality occupies a single functional head in the Cinque hierarchy. 
evidentiality is distributed across several functional heads, as in (97). We can now ask the question of whether the order of evidential morphemes, both with respect to each other and to other functional heads, reflects a universal hierarchy. More specifically, in the case of St'át'imcets, we can ask whether the order of evidential clitics respects such a hierarchy.

As noted earlier, the three evidential clitics discussed here form part of a second position clitic string consisting of fifteen or so more or less strictly ordered functional elements, including speech act markers, discourse particles, modals, and markers of temporal reference. As such, they provide a rather straightforward empirical test for the Cinque-Speas approach to evidentiality. The clitics are given below, together with their relative ordering in the clitic string, their gloss in van Eijk (1997), and their putative counterpart in the Cinque functional hierarchy:33

33 The clitics in (97) follow the order given by Davis (in prep.) which is a slight amendment of that in van Eijk (1997:207), to better reflect the usage of our own consultants. (One clitic, wen, is omitted from consideration here, since it is not used by our consultants.) We have retained the van Eijk glosses for consistency, but our analysis of many of the clitics differs from his. In particular, we treat kelh as a modal with a future tense orientation (see Matthewson to appear, Rullmann, Matthewson, and Davis 2006b) and tu7 as a temporal adverbial, not a tense or aspect marker (Davis and Matthewson 2003, Matthewson to appear). 


\begin{tabular}{|c|c|c|c|}
\hline POSITION & CLITIC & GLOSS & TYPE \\
\hline 1 & $-a n^{\prime}$ & 'evidential' & evidential/epistemic \\
\hline 2 & $\mathrm{a}$ & 'reinforcing' & - \\
\hline 3 & cwilh & 'after all, it turned out to be' & evaluative \\
\hline & ha & 'interrogative' & speech act \\
\hline 4 & qa7 & 'presupposed knowledge' & evaluative \\
\hline 5 & ku7 & 'quotative' & evidential \\
\hline & $k^{\prime} a$ & 'possibility, surmise' & evidential/epistemic \\
\hline 6 & ka & 'obligation, expectancy' & irrealis \\
\hline 7 & malh & 'adhortative' & speech act \\
\hline & wi7 & 'emphasis' & - \\
\hline & t'elh & 'contemporaneous' & - \\
\hline 8 & kelh & 'remote future, possibility' & future tense/epistemic modality \\
\hline 9 & hem' & 'antithesis' & - \\
\hline 10 & tu7, t'u7 & 'definite past', 'well, but, so' & past tense, - \\
\hline 11 & tu7, t'u7 & 'definite past', 'well, but, so' & past tense, - \\
\hline
\end{tabular}

A couple of general comments are in order. First, to the extent that the order of clitics corresponds to the Cinque hierarchy, it does so directly rather than in 'Mirror Principle' fashion - that is, the higher functional heads are closer to the predicate than the lower ones. This is because the clitic string is not derived by successive head movement of the predicate (see Davis 2004 for additional arguments against head movement above the affixal domain in St'át'imcets); rather, the clitics 
correspond to 'particles' in Cinque's sense, though as enclitics they end up to the right of the predicate. Second, what we find in St'át'imcets generally corresponds to the typologically unmarked order mood > tense (see Foley and van Valin 1984, Bybee 1985, Bybee, Perkins and Pagliuca 1994), but within the mood and tense domains, there is far more variation than predicted by the Cinque hypothesis.

Turning specifically to the position of evidentials, the order of enclitics reinforces two conclusions we have already reached. First, evidentials are distributed within the clitic string, rather than occupying a unique position. Second, they occupy a 'mood zone' which includes elements corresponding to Cinque's evidential mood, irrealis mood, evaluative mood, speech act mood, and epistemic modality projections, and is situated above (though overlapping with) a lower 'tense zone'. But beyond that, the positions of the individual evidential enclitics are clearly not predicted by the Cinque hierarchy. In fact, even were we to reclassify the two inferential enclitics as epistemic modals, their very different positions in the clitic string (one at the very beginning, the other following the reportative) would remain problematic.

These are perhaps not insuperable problems (for example, it could be argued that the distinctive morphological properties of -an' are responsible for its anomalous position in the clitic string). However, taken together with other language-internal and cross-linguistic evidence for the morphosyntactic heterogeneity of evidentials, they strongly suggest that any attempt to pin evidentiality to a single functional head is ultimately misguided. (Note that, for example, the perfect of evidentiality discussed by Izvorski (1997) is problematic for the Cinque-Speas approach, since here evidential semantics is linked to an aspectual projection, far down the Cinque hierarchy.)

A less restrictive approach to the (morpho)syntax-semantics mapping for evidentials is proposed by Blain and Déchaine (in press). Their leading idea is that evidentials are distributed in different domains (zones) of the clausal architecture, as follows: 

$\operatorname{Evid}\left[{ }_{\mathrm{CP}} \cdots\right.$
$\operatorname{Evid}\left[{ }_{\mathrm{IP}} \cdots\right.$
$\operatorname{Evid}\left[{ }_{A S P P} \cdots\right.$
$\operatorname{Evid}[\mathrm{vp} \cdots$
CP-EXTERNAL
IP-EXTERNAL
ASPP-EXTERNAL
VP-EXTERNAL

This distributed view of evidentials is clearly more consonant with our own approach (and more compatible with the cross-linguistic evidence) than the 'single head' view of Cinque and Speas. Moreover, Blain and Déchaine show on the basis of their examination of evidentiality in the Cree dialect continuum that elements from different morphosyntactic classes can contribute evidential information: for example, in their CP-external domain they include two reportative morphemes, one of which is a verb, the other a particle. This is similar to the situation in St'át'imcets, where as we have seen, a spatio-temporal demonstrative adverb represents non-visual information, while the three enclitics encode other evidential notions. And finally, unlike the Cinque-Speas account, the Blain-Déchaine approach predicts that evidentials may co-occur, as we have already seen in Korean and St'át'imcets. Blain and Déchaine show this is also the case for Cree, as in the following example, involving the reportative and dubitative morphemes:

êtikw[êe] âwa êkwa nicâhkos [a]wa êkwa sêmâk êsa k-êspayit

DUBIT this and.then my.sister.in.law this and.then right.away REPORT PERF-go(3)

$$
\begin{array}{llll}
\text { osîmisa } & \text { ê-asiwasoyit } & \text { 'hospital' } & \text { ê-nitawâpamât } \\
\text { her.brother(OBV) } & \text { CONJ-be.inside(3') } & & \text { CONJ-go.see(3-3) }
\end{array}
$$

= "And then reportedly my sister-in-law must have gone right away to see her younger brother in the hospital."

F "And then it must have been reported that my sister-in-law went right away to see her younger brother in the hospital." 
(Ahenakew 2007:70, cited in Blain and Dechaine in press)

Note that the fixed scope of the reportative relative to the dubitative shown in (99) is important for Blain and Déchaine, since they analyze the reportative as a CP-external operator, but the dubitative as an IP-external operator. ${ }^{34}$

More generally, Blain and Déchaine identify the following evidentials as exemplifying each of their four syntactic domains:

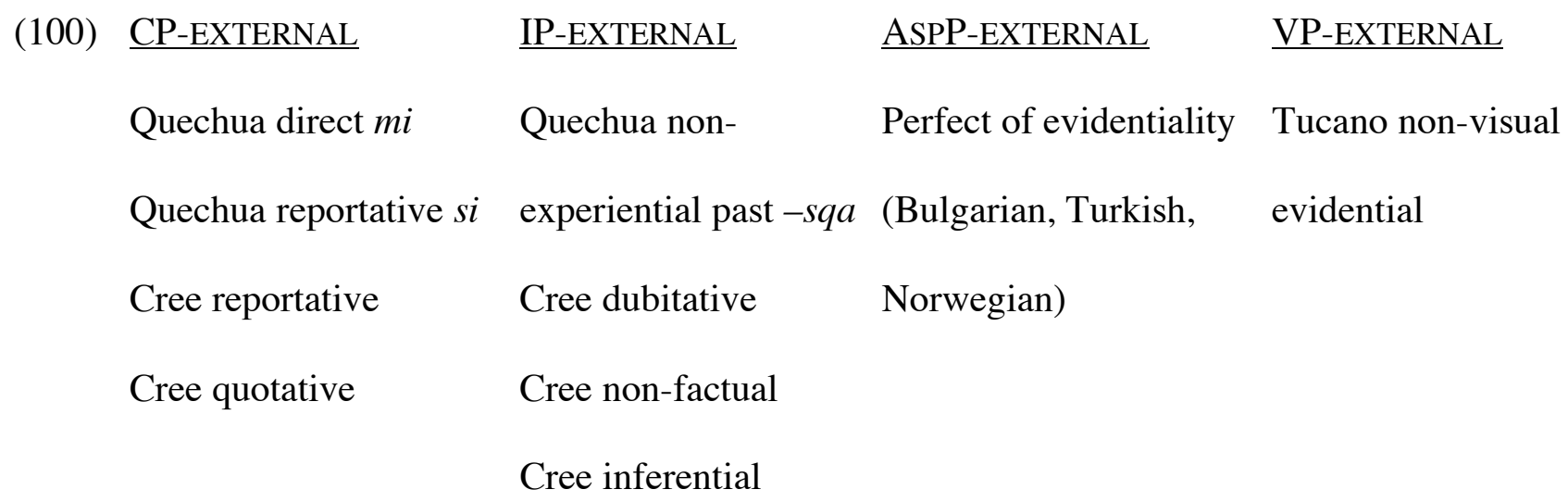

Though they do not explicitly make the claim that each syntactic domain is universally associated with a particular semantic type of evidential, it is certainly tempting to do so on the basis of the distributional pattern seen in (100). Under such a view, CP-external evidentials would be semantically equivalent to speech-act operators, as described by Faller for Quechua, and IP-external evidentials would correspond to epistemic modals, as in our analysis of the St'át'imcets evidential enclitics. A potential complication here would arise from the fact that the same notional category of

\footnotetext{
${ }^{34}$ An obvious question is whether the parallel St'át'imcets cases given in (97-98) or the Korean example in (106) also show fixed evidential scope. We do not yet know the answer to this question.
} 
evidential can be analyzed differently in the formal semantics of different languages (or even potentially in the same language). For example, we have claimed that reportatives can either be speech act operators (as in Faller's treatment of Quechua si) or epistemic modals (as in our treatment of St'át'imcets $k u 7)$. A 'domain-mapping' approach would predict that in the Quechua case, the reportative should be a CP-external operator (as Blain and Déchaine argue), but in the St'át'imcets case, it should be an IP-external operator. Evidence is currently lacking for the latter prediction; this is an issue for future research.

Turning to the lower evidential domains in (98), it is less clear how to differentiate AspPexternal operators semantically from IP-external operators, since - at least according to the analysis of Izvorski (1997), which we adopt - the perfect of evidentiality has the semantics of an epistemic modal, just like IP-external evidentials. And altogether too little is known about the semantics of non-visual evidentials (including St'át'imcets lákw7a) to say anything concrete about VP-external evidentials. 35

In other words, since many details of the domain-mapping approach have not been fully worked out, it is too early to judge it as a comprehensive theory of the syntax-semantics mapping for evidentials, though it certainly appears more promising than the 'single head' mapping approach of Cinque and Speas. We leave further exploration of this issue for future work.

\section{Conclusion}

Based on the evidence presented in this paper, we conclude that evidentiality is not a homogeneous

35 Blain and Déchaine suggest that non-visual modality may equate with the notion of 'agent control', which is a pervasive part of the semantics of Salish languages, and which may ultimately be amenable to a modal analysis. We leave this issue for further research. 
category, either semantically or syntactically. Cross-linguistically and even within a single language, evidentials (elements which encode information source) may or may not fall squarely into the category of epistemic modals. In most or perhaps even all languages, they do not form grammaticalized systems and cannot be analyzed as confined to a single position near the top of the functional hierarchy. It is in fact our contention that evidentiality per se is a 'parasitic' category. Evidential meanings may be associated with any of the principal functional heads in the IP domain: mood, tense, or aspect.

\section{References}

Ahenakew, A. 2000. Ah-ayitaw isi e-ki-kiskeyihtahkik maskihkiy: Cree Tales of Curing and Cursing. Ed. by C. Wolfart and F. Ahenakew. Winnipeg: The University of Manitoba Press. Aikhenvald, A. 2004. Evidentiality. Oxford: Oxford University Press.

Anderson, L.B. 1986. Evidentials, paths of change and mental maps: Typologically regular asymmetries. In W. Chafe and J. Nichols (eds.), Evidentiality: The Linguistic Coding of Epistemology. Norwood: Ablex Publishing Corporation, 273-312.

Blain, E. and R.-M. Déchaine in press. Evidential marking across the Cree dialect continuum. International Journal of American Linguistics.

Bybee, J. 1985. Morphology: A Study of the Relation Between Meaning and Form. Amsterdam: John Benjamins.

Bybee, J., W.D. Perkins, and W. Pagliuca 1994. The Evolution of Grammar: Tense, Aspect and Modality in the Languages of the World. Chicago: University of Chicago Press.

Chung, K. 2005. Space in Tense: The Interaction of Tense, Aspect, Evidentiality and Speech Act in Korean. Ph.D. dissertation, Simon Fraser University. 
Chung, K. in press. Toward an integrated theory of the perfect and the indirect evidential. Proceedings of NELS 36, GLSA.

Cinque, G. 1999. Adverbs and Functional Heads: A Cross-Linguistic Perspective. Oxford: Oxford University Press.

Davis, H. 2001. Kayám: an early St'át'imcets text. Anthropological Linguistics 43:1-59.

Davis, H. 2004. VP Ellipsis in St'át'imcets and its Implications. Papers for the 39th International Conference on Salish and Neighboring Languages. UBC Working Papers in Linguistics 14: 117-140.

Davis, H. in prep. A Teacher's Grammar of Upper St'át'imcets. Ms., University of British Columbia.

Davis H. and L. Matthewson 2003. A note on remote: The temporal enclitic $t u 7$ in St'át'imcets. Papers for the 38th International Conference on Salish and Neighbouring Languages. UBC Working Papers in Linguistics.

Davis, P. and R. Saunders 1975. Bella Coola deictic usage. Rice University Studies 61:13-35.

De Haan, F. Evidentiality and epistemic modality: Setting the boundaries. Southwest Journal of Linguistics 18:83-101.

Ehrich, V. 2001. Was nicht müssen und nicht können (nicht) bedeuten können: Zum Skopus der Negation bei den Modalverben des Deutschen. In R. Müller und M. Reis (eds.), Modalität und Modalverben im Deutschen, Vol. 9 of Linguistische Berichte Sonderhefte, 149-176. Hamburg: Buske.

Eijk, J. van 1997. The Lillooet Language: Phonology, Morphology, Syntax. Vancouver: UBC Press. Eijk, J. van and L. Williams 1981. Lillooet Legends and Stories. Mount Currie, BC: Ts'zil Publishing House. 
Faller, M. 2002. Semantics and Pragmatics of Evidentials in Cuzco Quechua. Ph.D. dissertation, Stanford.

Faller, M. 2003. Propositional- and illocutionary-level evidentiality in Cuzco Quechua. Proceedings of SULA 2, GLSA.

Faller, M. to appear. Evidentiality above and below speech acts. Functions of Language. (Special issue on evidentality, edited by C. Paradis and L. Egberg.)

von Fintel, K. 2005. Epistemic modals: A linguistic perspective. Paper presented at the APA Eastern Division, New York.

Foley, W.A. and R.D. van Valin 1984. Functional Syntax and Universal Grammar. Cambridge: Cambridge University Press.

Garrett, E. 2000. Evidentiality and Assertion in Tibetan. Ph.D. dissertation, UCLA.

Harley, H. and E. Ritter 2002. Person and number in pronouns: A feature-geometric analysis. Language 78:482-526.

Hengeveld, K. 1990. The hierarchical structure of utterances. In J. Nuyts, A.M. Bolkestein, and C. Vet (eds.), Layers and Levels of Representation in Language Theory. Amsterdam: John Benhamins, 1-24.

Hill-Tout, C. 1905. Report on the ethnology of the StlatlumH of British Columbia. Journal of the Anthropological Institute of Great Britain and Ireland 36:125-215.

Horn, L. 1989. A Natural History of Negation. Chicago: University of Chicago Press.

Ifantidou-Trouki, E. 1993. Sentential adverbs and relevance. Lingua 90: 69-90.

Izvorski, R. 1997. The present perfect as an epistemic modal. Proceedings of SALT VII: 222-239.

Klinedinst, N. 2005. Plurals, possibilities, and conjunctive disjunction. Paper presented at Sinn und Bedeutung 10. (To appear in the proceedings.) 
Kratzer, A. 1977. What "must" and "can" must and can mean. Linguistics and Philosophy 1: 337355.

Kratzer, A. 1981. The notional category of modality. In H.-J. Eikemeyer and H. Rieser (eds.), Words, Worlds, and Contexts, Berlin: de Gruyter, pp. 38-74.

Kratzer, A. 1991. Modality. In Dieter Wunderlich and Arnim von Stechow (eds.), Semantics: An International Handbook of Contemporary Research, Berlin: de Gruyter, pp. 639-650.

Kratzer, A. 1998. Scope or pseudo-scope? Are there wide-scope indefinites?. In S. Rothstein (ed.), Events in Grammar. Dordrecht: Kluwer.

Lecarme, J. 2005. Tense and modality in nominals. Paper presented at the International Roundtable on Tense, Mood and Modality, Université Paris 7.

Lyons, J. 1977. Semantics. Cambridge: Cambridge University Press.

McCready, E. and N. Asher 2005. Modal subordination in Japanese: Dynamics and evidentiality. $U$. Penn. Working Papers in Linguistics 10.

McCready, E. and N. Ogata 2006. Evidentiality, modality and probability. Ms., Aoyama Gakuin University and Osaka University.

Matthewson, L. 1998. Determiner systems and quantificational strategies: Evidence from Salish. The Hague: Holland Academic Graphics.

Matthewson, L. 1999. On the interpretation of wide-scope indefinites. Natural Language Semantics 7:79-134.

Matthewson, L. 2005. When I was Small - I Wan Kwikws: Grammatical Analyis of St'át'imc Oral Narratives. Vancouver, BC: UBC Press.

Matthewson, L. to appear. Temporal semantics in a superficially tenseless language. Linguistics and Philosophy. 
Matthewson, L., H. Rullmann and H. Davis 2005. Modality in St'át'imcets. Papers for the 40th International Conference on Salish and Neighbouring Languages. UBC Working Papers in Linguistics. Also published in MIT Working Papers in Endangered Languages: Studies in Salishan, ed. S. Bischoff, L. Butler, P. Norquest and D. Siddiqi, 93-112 (2006).

Matthewson, L, H. Rullmann and H. Davis 2006. Evidentials are epistemic modals in St'át'imcets. Papers for the 41st International Conference on Salish and Neighboring Languages. UBC Working Papers in Linguistics 18: 211-263.

Mithun, M. 1999. The Languages of Native North America. Cambridge: Cambridge University Press.

Palmer, F. 2001. Mood and Modality. Cambridge: Cambridge University Press.

Pancheva, R. 2005 Tense and evidentiality. Paper presented at the International Roundtable on Tense, Mood and Modality, Université Paris 7.

Papafragou, A. 2000. Modality: Issues in the Semantics-Pragmatics Interface. Amsterdam: Elsevier.

Portner, P. 1997. The semantics of mood, complementation, and conversational force. Natural Language Semantics 5:167-212.

Reinhart, T. 1997. Quantifier scope: How labor is divided between QR and choice functions. Linguistics and Philosophy 20:335-397.

Rooryck, J. 2001a. Evidentiality, Part I. GLOT International 5:125-133.

Rooryck, J. 2001b. Evidentiality, Part II. GLOT International 5:161-168.

Rullmann, H., L. Matthewson and H. Davis 2006a. Modals as specific indefinites. Ms., University of British Columbia.

Speas, M. 2004. Evidentiality, logophoricity, and the syntactic representation of pragmatic features. Lingua 114:255-276. 
Speas, M. 2006. Evidential paradigms, world variables and person agreement features. Ms., University of Massachusetts, Amherst.

Sweetser, E. 1990. From Etymology to Pragmatics. Cambridge: Cambridge University Press.

van Valin, R.D. and R.J. LaPolla 1997. Syntax. Structure, Meaning and Function. Cambridge: Cambridge University Press.

Willett, T. 1988. A cross-linguistic survey of the grammaticization of evidentiality. Studies in Language 12:51-97.

Winter, Y. 1997. Choice functions and the scopal semantics of indefinites. Linguistics and Philosophy 20:399-467. 